
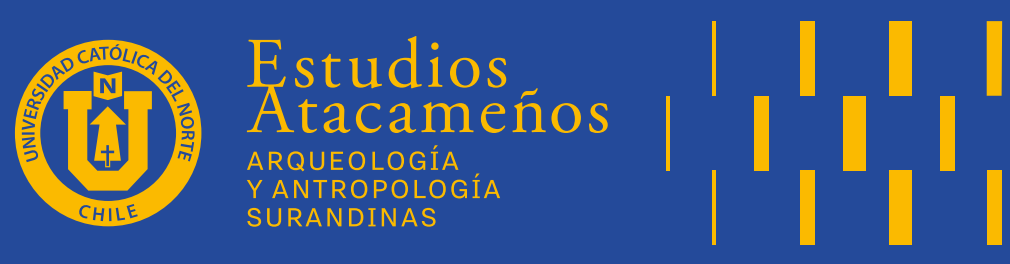

\title{
"E aqí, pues, dos razas distintas". Paradigmas raciales en Chile (siglos XVIII-XXI): significados y deslindes conceptuales
}

\section{"E aqí, pues, dos razas distintas". Racial paradigms in Chile (XVIIIth-XXIth century): meanings and conceptual demarcations}

\author{
Montserrat Arre Marfull1 (D) https://orcid.org/0000-0002-0156-1358 \\ Tomás Catepillán Tessi² (D) https://orcid.org/0000-0002-1387-1484 \\ ${ }^{1}$ Instituto de Estética de la Pontificia Universidad Católica de Chile, CHILE. \\ Email: montserrat.arre.marfull@gmail.com \\ ${ }^{2}$ Instituto de Historia de la Pontificia Universidad Católica de Valparaíso CHILE. \\ Email: tomas.catepillan@gmail.com
}

\section{Resumen}

En este artículo abordamos los distintos paradigmas raciales que han operado en el Reino y posterior República de Chile. Nos interesa proponer una definición histórica del concepto raza (concepto inestable, relacional, multifuncional y localizado), organizar y sintetizar una parte de la abundante literatura sobre el tema y, por último, definir los dos principales paradigmas raciales que han operado y operan actualmente, como sustratos emergentes, en lo que hoy denominamos Chile. Realizamos una reflexión sobre las ideologías del mestizaje que en esta república sudamericana todavía circulan y funcionan con ciertas pretensiones de integración pluralista, y son utilizadas por un arco enorme de personas que incluye agentes del Estado, población indígena, chilenos nacionalistas o críticos del nacionalismo. Proponemos en este artículo que la idea de raza ha servido para denominar y producir las diferencias humanas, que los racismos generalmente han tenido móviles políticos, y que los paradigmas raciales que abordamos se hayan presentes, como sustratos, en los modos con que actualmente los chilenos piensan las diferencias humanas.

Palabras clave: raza, racismo, mestizaje, identidades, nación, Chile, América Latina.

\begin{abstract}
In this paper we differentiate the racial paradigms that have operated in the Reino and later República de Chile. Our aims are to propose a historical definition of the race concept (an unstable, relational, multifunctional and located concept), to organize and synthesize part of the plentiful literature about the topic, and finally, to define the two principal racial paradigms that have operated and actually operate, as emergent substrates, in what we now name Chile.
\end{abstract}


We ponder about the mestizaje ideologies which, in this South American republic, still circulates and works with some ambitions of pluralistic integration, an so, they are used by a huge spectrum of people, including State agents, native population, Chilean nationalists and critics of the nationalism. We propose in this paper that the race idea has served to nominate and to produce the human differences, that the racisms generally has had politic motivations, and that the racial paradigms that we define in this paper are present, as substratum, in the way that Chilean people think the human differences.

Keywords: race, racism, mestizaje, identities, nation, Chile, Latin America.

Recibido: 14 noviembre 2019. Aceptado: 21 marzo 2020 


\section{Introducción}

Es conocida la anécdota de Johann Jakob Von Tschudi. La cuenta Marisol de la Cadena (2007b) en un texto al cual debemos mucho. El naturalista suizo llegó al Perú en 1838, y se asombró de los colores de las personas, pero más aún de lo que le parecía una especie de engańo: en la sierra había gente que se decía espańola, a pesar de que eran en verdad (a juzgar por su apariencia) indígenas. Como lo señala De la Cadena, es evidente que en aquella afirmación entran en contradicción las nociones raciales de Von Tschudi con las nociones raciales de los mismos peruanos que decían ser españoles. Este desencuentro, sin embargo, no solo le ocurrió a Von Tschudi. Así como a él, es probable que sucediera con todos los científicos europeos que visitaban estas partes del mundo en el siglo XIX. Leamos, por ejemplo, la impresión que le produjo a Charles Darwin la población de Chiloé luego que recorriera aquella provincia durante el mítico viaje del Beagle:

Muchos de los habitantes de Chiloé que no tienen apellidos indios no se distinguen de estos por sus apariencias. Gómez, el gobernador de Lemuy, es descendiente de nobles españoles por ambos lados. Y sin embargo, a causa de los constantes matrimonios inter raciales con los nativos, es de hecho un indio (Darwin, 1860, p. 276). ${ }^{1}$

Si las historiadoras e historiadores hubieran sido más sensibles a las lógicas o paradigmas raciales de aquellos pobladores de la sierra peruana, de la provincia de Chiloé y probablemente de cualquier parte de este continente, nos habríamos ahorrado buena parte de las confusiones sobre el tema que nos convoca. Porque no cabe duda de que es más común encontrar trabajos que hagan eco de las nociones raciales de Von Tschudi y Darwin que de las nociones raciales de aquellas personas "equivocadamente" denominadas espańolas, e incluso mestizas. En parte aquello ocurre por la geopolítica del conocimiento y, en consecuencia, porque las nociones raciales de Charles Darwin nos resultan mucho más comprensibles que las del gobernador de Lemuy.

Pero descartemos de entrada que las contradicciones que aparecen en Von Tschudi y Darwin son en verdad "equivocaciones", acaso impostaciones interesadas de peruanos y chilotes, y abrámonos a la posibilidad de que sean usos racionales y conformes a lógicas o paradigmas raciales distintos a los que, quizá desde antes de la Ilustración, hegemonizan en Occidente la manera de comprender las diferencias humanas.

Ya se ha afirmado, y con justa razón, que tanto cambian las palabras y no las cosas que denominan como se modifica aquello que nombran sin que cambien las palabras (Bloch, 2001, p. 154). Es el caso, nos parece, de las voces "mestizo" y "raza". Esta constatación, de la que nuestras y nuestros colegas pueden dar sobradas pruebas, no agota los objetivos de este artículo (Pérez Vejo y Yankelevich, 2018). ${ }^{2}$ Junto con detallar los modos sucesivos en que se han comprendido estas dos voces, tan caras en la América Latina y Chile, nos interesa abordar sumariamente los

1 Traducción de T. Catepillán. En el original: "Many of the inhabitants [...] [without] Indian surnames, cannot be distinguished by their appearance from Indians. Gomez, the governor of Lemuy, is descended from noblemen of Spain on both sides; but by constant intermarriages with the natives the present man is an Indian".

2 Así lo exponen y discuten todos los autores y autoras de la excelente obra compilada por Tomás Pérez Vejo y Pablo Yankelevich. 
procesos mediante los cuales tomaron forma. Nos parece que a través del estudio de estos procesos quedará claro el carácter nómade e híbrido tanto de la "raza" como del "mestizo", y aun de las diversas ideologías del mestizaje elaboradas en este continente al alero de los varios procesos de construcción de la nación (Braidotti, 2004; De la Cadena, 2007a, 2007b).

En otras palabras, hacemos extensiva, en general, a los conceptos con los que se han marcado las diferencias humanas, aquella poderosa idea de que el mestizo no solo denomina una hibridez "empírica"; primeramente, es el signo de cierta hibridez conceptual (De la Cadena, 2007b, p. 86). Esto es lo que queremos resaltar cuando hablamos de dos grandes paradigmas raciales que coexisten como sustratos emergentes. Sustratos que se actualizan de diversa manera en lugares y tiempos específicos, que están vinculados a procesos culturales más amplios y que, alternadamente, han sabido ser pujantemente hegemónicos, a pesar de que podamos verlos hoy en día como "tradicionales" o "populares".

En suma, en este artículo proponemos una definición histórica del concepto raza, organizamos y sintetizamos la bibliografía sobre el tema que nos ha parecido más pertinente y definimos los dos principales paradigmas raciales que han operado y operan actualmente, como sustratos emergentes, en lo que hoy denominamos Chile. Intentaremos, por lo mismo, responder estas dos preguntas: ¿cómo se ha comprendido históricamente el concepto raza en Chile? y ¿qué sobrevive de aquellos usos en la actualidad?

Como se puede apreciar, a lo largo de este artículo recorreremos un gran arco de tiempo que nos llevará desde los tiempos de la monarquía hasta el presente. Y se trata de una cuestión que, a pesar de la crítica académica, nos parece fundamental para el propósito de contribuir no solo a la economía de los papers, sino también a la sociedad chilena en su conjunto. Por lo mismo, en la conclusión abordaremos dos cuestiones como contrapunto al desarrollo del cuerpo de este artículo: un análisis general del ejercicio de la genómica contemporánea y una propuesta de lo que pudo ser el antiguo paradigma racial mapuce (Cańumil, Cańumil y Berretta, 2008). ${ }^{3}$

Nos interesa dejar en claro que no adoptamos una definición específica del concepto raza. Es conocido que, en la investigación histórica, adoptar una definición teórica específica a menudo dificulta la comprensión de conceptos amplios y con multiplicidad de interpretaciones (Chiaramonte, 2004, p. 30). Nos parece suficiente aclarar en esta introducción que "raza" es un concepto que ha sido utilizado, inclusive hoy, para denominar (i.e., producir) y controlar las desigualdades humanas. Desigualdades relacionadas, alternativamente, con el credo y las prácticas religiosas, con el lugar de nacimiento y residencia, con el color y las formas de los cuerpos, pero también con el idioma, las comidas, etcétera. Desigualdades, por último, siempre articuladas en torno a la genealogía o el vínculo entre las generaciones.

En otras palabras, y no nos apena repetirlo, consideramos el concepto raza como multifuncional, necesariamente híbrido, inestable, producido de manera relacional y siempre en contextos específicos. Nómade, en términos de Rosi Braidotti, pues el nomadismo es un concepto que se relaciona con traspasar fronteras, deslocarse, comprenderse o presentarse, intencionalmente o no, en un estar múltiple o en una situación resultante de las múltiples determinaciones que, a la vez, son tanto diversas como dinámicas. Así, la idea de "concepto nómade" o "subjetividad

3 Todas las palabras en mapuzugun las escribimos siguiendo el sistema de A. Raguileo, y respetando la ortografía y gramática de dicho idioma. 
nómade" propone des-localizar o multi-localizar la reflexión en torno a la concepción racial (Braidotti, 2004, pp. 210-215).

De este modo los "paradigmas raciales" serían aquellos conjuntos más o menos articulados de ideas y asociaciones que, en determinado tiempo y lugar, la gente ha utilizado (y utiliza) para marcar la diferencia y la desigualdad y, por lo mismo, para dominar a aquellos identificados como desiguales. En consecuencia, nos parece que ya existían paradigmas raciales antes de que se hicieran hegemónicas las teorías raciales generalmente llamadas "científicas", al punto de que podamos encontrarlos en Europa previo a la era de las navegaciones atlánticas, así como siguen existiendo paradigmas raciales a pesar de la purga que la palabra raza ha sufrido en las últimas décadas (Bethencourt, 2015, p. 26). ${ }^{4}$

Otro punto importante a destacar en esta introducción es el de los sustratos emergentes, de los cuales ya hemos referido algo. En este artículo abordaremos fundamentalmente dos grandes paradigmas raciales, como las "dos razas" de la cita con que titulamos el artículo (López, 1845, p. 36). No creemos, sin embargo, que estas formas de comprender la raza hayan desaparecido sucesivamente. Nos parece, en cambio, que se sobreponen y coexisten en combinaciones diversas, no siempre libre de tensiones, dependiendo de los peculiares entramados de cada sociedad y aun de cada región y localidad. En otras palabras: conviven hasta cierto punto como sustratos, pero sustratos en movimiento, capaces de emerger y actualizarse. No es casualidad que, redactando este artículo, recordáramos el comportamiento de ciertas masas de agua fría que afloran a la superficie en la corriente de Humboldt, asegurando con esto su color y temperatura (De la Cadena, 2007a, 2007b; Arias y Restrepo, 2010; Bethencourt, 2015).

Los paradigmas raciales que referiremos son el del Antiguo Régimen o tradicional, que aborda la genealogía de manera narrativa, es decir, la narración del linaje humano, la selección de líneas específicas para explicar la ascendencia de una persona, destacando lo más noble o abyecto (según los parámetros de cada época y lugar), además de la presentación que cada quien hace de sí, que influiría en la raza a la que se dice (o dice) pertenecer una persona; y el paradigma cientifico ilustrado, que aborda la genealogía en términos biológicos (cuerpos) partiendo por la Historia Natural (Arias y Restrepo, 2010, p. 58) y, por tanto, que ha definido la raza en concordancia con el desarrollo histórico de esta ciencia, que derivaría en las posteriores zoología, mineralogía, botánica y antropología decimonónicas, entre otras disciplinas.

Dentro de este segundo paradigma, abordaremos una formación específicamente nacional que hemos denominado el paradigma liberal de la república, que bien podría sintetizarse en las diversas ideologías del mestizaje que la misma república ha prohijado. Como añadido, cerraremos el artículo con un contrapunto en el cual abordaremos las "confusiones" identitarias que derivan de la genómica contemporánea y las características de cierto paradigma racial mapuce.

Es necesario aclarar que abrevamos en la abundante bibliografía que existe sobre este tema para toda la América Latina, pero insistimos en centrar nuestras reflexiones en lo que actualmente

4 Una purga, por otra parte, indudablemente vinculada a la asociación de este vocablo con las prácticas políticas de exterminio y segregación de los siglos XIX y XX. De modo que, como aclara Bethencourt, no es posible usar el concepto "raza" de manera neutra y sin aclarar los significados específicos con que se usa en determinado texto. 
es la República de Chile. Una república en la cual las políticas raciales han sido consistentemente veladas, en una eufemística construcción discursiva de la homogeneidad, como efecto un tanto inesperado de su curioso, conservador y romántico liberalismo fundacional (Pérez Vejo y Yankelevich, 2018, p. 11). ${ }^{5}$ Una república, de todos modos, que ha desarrollado políticas raciales específicas a lo largo de doscientos años. Una cita de Vicente Fidel López puede darnos el tono:

[P]ara saber qe ai dos clases de ombres en Chile qe son dueños del territorio, os bastará pensar qe ai una clase qe vive en ciudades, qe abla el idioma español, qe se viste siguiendo las modas europeas, qe aprende en escuelas las ciencias; i en fin, qe vive bajo el influjo de leyes i gobiernos civilizados; al paso qe ai otra clase qe vive en los campos desiertos, qe abla un idioma qe nosotros no comprendemos, qe no usa nuestros vestidos ni se pone los vestidos usados en Europa, qe no tiene libros, escuelas, leyes escritas, ni gobiernos civilizados en fin. E aqi, pues, dos razas distintas [...] (López, 1845, pp. 33-36). ${ }^{6}$

El artículo que presentamos, para cerrar esta introducción, pretende reflexionar y llegar a cierto consenso respecto de la común idea de la aparición de raza en el imaginario a fines del siglo XVIII, palabra que se establecería como el pilar fundamental de las ciencias humanas y biológicas desde ese entonces (Pérez Vejo y Yankelevich, 2018), pero que, según nuestra propuesta, no se manifiesta en cuanto a sus diversos contenidos desde ese momento, sino que ya era un concepto funcional mucho antes, fuese en su versión nominal de raza o en sus formas semánticas emparentadas como lo son sangre, calidad o casta.

\section{Paradigma Tradicional o del Antiguo Régimen: raza, sangre, calidad y casta}

Si bien hemos adoptado la última oración de la cita de V. F. López en el título para hacer un alcance a los dos paradigmas raciales que abordamos en este artículo, también nos sirve para comenzar a pensar este primer apartado. Después de todo, aparecen en las palabras de este autor algunas ideas respecto de la raza que contradicen, y en mucho, las opiniones que citamos de Von Tschudi y Darwin. Tendremos a fuerza que ahondar en la lógica desde la cual se vuelven comprensibles las razas de las que habla López, que a vuelo de pájaro parecen ser definidas sobre todo en términos culturales (un lugar de residencia, cierto idioma, cierto gobierno, ciertos vestidos). Por ahora, bástenos traer a colación otra cuestión: el binarismo racial, o la proposición de que existían en 1845 verdaderamente dos razas distintas bajo el gobierno de la República de Chile.

Aunque pueda resumirse en un genérico "nosotros" y "los otros", nos parece que en V. F. López late una característica fundacional de las sociedades coloniales en Hispanoamérica.

5 Según Pérez Vejo y Yankelevich, la idea decimonónica de los derechos políticos en función de la raza no vinieron del tronco central de la Ilustración, el liberalismo, sino de una "extraña deriva de este" que se sitúa en el movimiento romántico.

6 Las cursivas son nuestras. Vicente Fidel López (1815-1903), abogado, historiador, novelista, profesor y político bonaerense, estuvo exiliado en Chile casi 13 años durante el gobierno de Rosas. Inició su carrera de profesor de historia y retórica en el Instituto Nacional y la Universidad de Chile. Se lo conoce como uno de los grandes historiadores argentinos. Polemizó con Bartolomé Mitre en cuanto a cómo escribir y enseñar la historia de Argentina. 
Precisamente, la pretensión de que dichas sociedades estaban compuestas por los españoles, la generación de los conquistadores, y por los indios, la generación de los conquistados. En pocos lugares esta forma original de pensar las sociedades coloniales sobrevivió a la experiencia concreta de esas mismas sociedades. Y, sin embargo, podemos encontrar huellas de este binarismo desde Nueva España a las pampas bonaerenses.

Y aclaramos que las sociedades coloniales solo teóricamente fueron pensadas en estos términos. En primer lugar, porque los límites entre conquistados y conquistadores no siempre fueron claros. Y, en segundo lugar, porque del tráfico de esclavizados de origen africano ${ }^{7}$ y de la unión de gentes de orígenes diversos resultó el desarrollo de un grupo humano heterogéneo genéricamente nombrado con la palabra -en plural- de castas. De aquí que sea usual el uso "sociedad de castas" para hablar de la sociedad colonial, a pesar de lo cual ningún nominado español en ninguna de las muchas ciudades fundadas entre los siglos XVI y XVIII habría dicho que pertenecía a la "casta española"; como mucho, se habrían denominado castos o castizos (Araya Espinoza, 2010, p. 346). ${ }^{8}$

Y, sin embargo, la idea de una "sociedad de castas" nos resulta útil, siempre y cuando seamos sensibles a la importancia de la calidad (Undurraga Schüler, 2012, pp. 147-167), el linaje, el color y la "pureza de la sangre" como principales diferenciadores." Con todo, el sistema de castas colonial comenzó a perfilarse paulatinamente desde el siglo XVI en la América española y portuguesa. Su origen lo encontramos en la experiencia de la llamada reconquista ibérica sumada al proceso de expansión marítimo anterior a Colón, que generó una estructuración social y legal que sería sistematizada y complejizada hacia el siglo XVIII en América.

Para caracterizar lo que hemos llamado paradigma racial tradicional o del Antiguo Régimen, revisaremos brevemente la genealogía epistémica o "anterioridades" (De la Cadena, 2008, pp. 1-24) de los conceptos raza y casta, que forman parte de un mismo campo semántico relativo a la clasificación humana, en contexto de diversidad o choque cultural, y que se han intersecado a lo largo de sus historias.

En el mundo ibérico, de los siglos previos y posteriores a la hegemonía cristiana, la raza hacía referencia a la traza o mancha de sangre judía o musulmana, que estaba presente en los cristianos nuevos o en sus descendientes, es decir, los conversos y moriscos respectivamente. Este conjunto de personas, como ya es sabido, considerado descendientes de antiguos infieles, podía quedar, y de hecho quedaba, excluido de ciertos espacios o eran, incluso, procesados por el Tribunal de la Inquisición en caso de sospecha de no haber abandonado del todo sus costumbres religiosas.

Es decir, por tener "raza de moro o judío", era posible que un sujeto determinado tuviese impurezas de cualquier tipo a razón de la mácula indeleble en el linaje (Burns, 2007, pp. 35-36; Hering Torres, 2007, p. 18; Bethencourt, 2015, pp. 57-63, 81-100). En estos casos, haberse

7 Según el proyecto de la UNESCO denominado "La ruta del esclavo", se ha calculado que durante 400 años ingresaron a América aproximadamente 11 millones de africanos. Este número es el que llegó, pues se estima que la cantidad que fue capturada en África podría haber ascendido a 33 millones, de los cuales dos tercios habrían muerto en las rutas africanas y en el tránsito oceánico.

8 El castizo o de linaje noble es quien ostenta una buena línea y descendencia, de ahí que el término "espańol" en América se transformara en una metáfora de buen linaje.

9 Pureza de sangre desde la tradición peninsular, que implicaba no tener ancestro judío o moro, y desde la tradición americana, que implicaba no tener ancestro indio y, más aún, no tener ancestro negro. 
bautizado y convertido al catolicismo no aseguraba a una persona o a sus descendientes ser integrados plenamente a la sociedad, pues era de común conocimiento el juicio que caía sobre los linajes de conversos. De esta manera, tener raza implicaba ser considerado no tan solo moral, sino también corporalmente impuro, y por tanto sujeto a los duros estatutos de limpieza de sangre (Bethencourt, 2015, p. 60). ${ }^{10}$

Algo de dicho imaginario de raza se entrelazaría con la noción de casta que se desarrolló durante los siglos posteriores a la conquista en América. Comprenderemos de esta manera el paradigma racial tradicional o de Antiguo Régimen: una diferenciación por la mácula del linaje que, pese a estar asociada a la sangre, no procede exclusivamente del cuerpo, sino mayormente de las prácticas culturales, es decir, de la lengua, la religión y las costumbres. En otras palabras, la cultura "no aceptada" por la hegemonía cristiana fue transformada en un rasgo hereditario que desacreditaba a las generaciones futuras y que, en tanto raza, se traspasaba por la sangre. Por otra parte, si bien en este paradigma la raza se pensó como una característica inherente a cada individuo, nos parece claro que se trataba de una característica particularmente opaca e interactiva. De ahí que a nosotros nos parezca atractivo pensar este paradigma como una forma narrativa: la raza se habría constituido a partir de lo que uno decía ser y de las formas en que era reconocido (genealógicamente) por los otros. Esta narrativa y su reconocimiento, por último y como podrá suponerse, no solo se relacionaban con los comportamientos, sino también con las específicas relaciones de linaje que una persona podía pretender y con las relaciones de ascendencia (para bien o mal) que los otros podían reconocerle (Lorandi, 1997). ${ }^{11}$

La casta o las castas, concepto que posee otro origen y aplicación, aunque igualmente se relaciona con la idea de linaje, ostenta un contenido que establece una organización en un sentido más bien de estratos o grupos con diferencias ocupacionales, legales y prerrogativas particulares en una sociedad dada, que poseen un correlato racial, entendiendo lo racial como una mixtura entre origen lingüístico/geográfico, religión y biología.

La casta, si intentamos historizar brevemente esta palabra, sería una voz oriunda de la Península Ibérica, común a las lenguas romances de aquella zona. Antes de la expansión atlántica, habría significado "especie animal", "raza o linaje de hombre" o "clase, calidad o condición" (Corominas, 1984, pp. 913-916). Luego de que los portugueses utilizaran el término casta para calificar las clases sociales hereditarias de la India, la palabra se propagó con este nuevo sentido a otras lenguas occidentales como el inglés, el alemán, el francés y el italiano (Corominas, 1984, p. 914). En América, sin embargo, las castas fueron el conjunto abigarrado de gentes resultante del cruce entre espańoles o portugueses, "negros" e "indios" (Bethencourt, 2015, pp. 222-239). No existió, de esta manera, una casta de peninsulares o cristianos viejos, porque las castas americanas denominaban cierta mancha relativa a la sujeción servil de los conquistados y esclavizados. A saber: un linaje en el cual los ascendentes no eran exclusivamente cristianos y, por ende, tampoco eran exclusivamente peninsulares (independiente de

10 La sistematización de la segregación judía y musulmana en territorios cristianos no fue creada por Castilla y Aragón en el siglo XV, sino que tiene una larga historia tanto en la misma península como en otros reinos europeos o en el Levante. Por ejemplo, la utilización de un distintivo de color amarillo para seńalar a los judíos, tan conocido por su uso durante el nazismo, fue una práctica utilizada en el antiguo Imperio turco, así como se les exigía a los cristianos llevar otro color para distinguirlos. Igualmente ocurrió con las vestimentas, algunas de las cuales eran prohibidas a judíos y cristianos en aquel contexto musulmán. Estas prácticas serían replicadas en la monarquía católica.

11 Ana María Lorandi nos habla de un caso relativo a estas inestabilidades y cruces en la "narración" de la propia "estirpe" como es el del "inca" Pedro Bohórquez en el siglo XVII. 
que el mismo devenir de la península ibérica contuviera una amalgama de mixturas igualmente complejas).

En la práctica, el vocabulario de las castas organizaba el entramado social que poco a poco se difuminaba a raíz de las posibilidades concretas de relaciones entre personas de distintas calidades. Una posibilidad que dependía, hasta cierto punto, de la eliminación del gran conflicto racial del mundo ibérico, cuajado en el principio de la "limpieza de sangre", es decir, la diferenciación religiosa.

Sobrepasado este conflicto a través de la sistemática cristianización más o menos obligada de los indios, y mediante el bautismo sin excepción de los esclavos al ser ingresados a los barcos negreros portugueses o bajados de ellos en tierras hispanas, se volvió necesario establecer las funciones sociales de estos grupos diferenciados. En contraste con el simple divisionismo de conquistadores ibéricos, indios tributarios y negros esclavos, que podemos observar desde una perspectiva alejada, si acercamos el lente a espacios concretos, llegaremos a ver un intrincado compuesto de relaciones económicas y familiares generadas a partir de estas mixturas permitidas entre cristianos de diversas castas, pero con posiciones socioeconómicas relativamente equivalentes, oficios similares y residentes en los mismos espacios geográficos.

Es decir, los matrimonios ungidos por la Iglesia, solo por poner ejemplos en abstracto, entre una india de encomienda y un esclavo negro, o de un español artesano y una mulata libre manumitida que tuvo hijos antes de serlo, y que por lo tanto se mantenían en cautividad, o de un zambo encomendado con una cuarterona libre, y así una infinidad de posibilidades, fue dando como resultado, en estos casos legítimos pero también los ilegítimos, una gama interminable de variedades en estas agrupaciones socio-raciales que se denominaron castas (Grubessich, 1992; Contreras Segura, 2013; Valenzuela Márquez, 2018).

Aun así, la casta actúa como un concepto mucho más asible en su definición teórica de lo realizable que fuera en la práctica (Araya Espinoza, 2010). ${ }^{12}$ Junto a ello queremos agregar, por otro lado, que la palabra raza teóricamente funciona, especialmente desde fines del siglo XVIII, como concepto intercambiable por una diversidad de posibilidades: raza es cultura, raza es lengua, raza es religión, raza es color de piel, raza es posición socio-legal, raza es nivel civilizatorio, en fin. Casta, en sencillo y para Iberoamérica, era la posición asignada a una persona según donde nacía y cómo se desarrollaba en una sociedad en relación al contenido de su linaje y su apariencia, lo cual podía o no tener un correlato en sus prácticas culturales.

La casta, en definitiva, era el grupo de pertenencia de una persona determinada fundamentalmente por sus atributos sociales y su apariencia en la sociedad colonial: las castas son los negros y sus mixturas con indio y con "blanco" (espańol en el caso de Hispanoamérica), a saber, mulato, zambo, cholo, cuarterón, mestizo, pardo, moreno y otros tantos apelativos. Ser de casta era peyorativo, de todas maneras, por la existencia de una línea divisoria entre lo "puro y blanco" y todo lo demás. Un "todo lo demás", las castas, definido por la mezcla: por las distintas mezclas que jugaban un papel definitorio en cuanto al posicionamiento jerárquico de los sujetos. A mayor mixtura con negro-esclavo y con indio (o con ciertos tipos de indios que fueron vistos como especialmente inferiores), mayor la subordinación social (Araya Espinoza,

12 Alejandra Araya Espinoza se refiere a la conflictividad para organizar y comprender el alcance de las clasificaciones sociales en padrones, censos y matrículas coloniales, en torno a categorías como clase, calidad y casta. 
2010, pp. 348-349). No obstante, estas jerarquías tampoco fueron absolutas, y ahí están los muchos casos de estas redes y cruces clasificatorios de los que nos hablan una cantidad no menor de historiadoras e historiadores chilenos. ${ }^{13}$

Para recapitular, estableceremos la idea de castas en el mundo iberoamericano y chileno como la manera en que la sociedad intentó mantener un orden estamental tradicional o de Antiguo Régimen, a partir, sin embargo, de una idea relativamente nueva y en constante actualización: la raza (aunque esta última noción no se usó de manera extensiva y sistemática sino hasta el siglo XVIII). Aquella idea de raza que tomó fuerza hacia el siglo XVIII, y sobre todo en el siglo XIX, no provenía de la idea de "mancha" de judío o moro, símil de sangre impura, sino que fue un replanteamiento mayor de la raza como modo de clasificación humana en general, más allá de la sociedad americana en particular (González Undurraga, 2011, p. 1494). ${ }^{14}$ Podríamos aventurar que la raza le debe mucho a la casta en su conformación decimonónica, aunque de maneras diversas y dependiendo de cada contexto particular, o de las específicas formaciones provinciales y nacionales de la alteridad (Briones, 2005; Gleizer y López, 2015; López, 2017; De la Cadena, 2007b). He ahí la complejidad de dirimir estas diferencias. Pero nos estamos adelantando.

Otro de los conceptos ampliamente utilizados, de raigambre ibérica y aplicado a las sociedades coloniales fue el de "calidad". La calidad de las personas tenía relación directa con la posición socio-racial o casta a la que pertenecian o con la cual se identificaban. Sin embargo, dicha posición era mudable, en muchas ocasiones, en una misma persona. Según Verónica Undurraga Schüler, existieron por lo menos tres variables que permitieron entender las calidades en el mundo colonial. En primer término, estaban las "identidades fenotípicas", en las que el color desempeñó un papel central. En segundo lugar, las "identidades oficiales", que aparecían en los registros de bautismo, matrimonio y defunción. Y, por último, las "identidades sociales", que referían a la reputación con la que cada uno era conocido y tratado en la vida cotidiana (Undurraga Shüler, 2012, p. 150; Castillo Palma, 2001). ${ }^{15}$

Calidad, nos dice Alejandra Araya Espinoza, siguiendo a Roland Anrup y María Eugenia Chávez, consigna un conjunto de propiedades inherentes a algo o alguien que permite apreciarlo como igual, peor o mejor que los restantes de su especie o, asimismo, al estado de una persona, su origen, edad y demás circunstancias y condiciones que se requieren para un cargo o dignidad (Araya Espinoza, 2010, p. 345).

Por lo tanto, la calidad de la persona era la vara de medida para situar o posicionar a dicha persona en un lugar determinado en un momento dado. Era la suma entre la percepción que se tenía de ese sujeto, en cuanto a sus atributos físicos, lo que se sabía de él en tanto su linaje y familia, sumado a su fama pública gestada en su espacio inmediato de acción. De aquí procede

13 Alejandra Araya Espinoza, Hugo Contreras Cruces, Carolina González Undurraga, María Eugenia Albornoz, Verónica Undurraga Schüler, Jaime Valenzuela Márquez, por nombrar algunos de las y los historiadores chilenos más actuales de referencia obligada.

14 Algo de esto es señalado por Carolina González Undurraga, si bien, de manera general: considera que para mediados del siglo XIX es posible encontrar en el concepto "raza" elementos articulados por el concepto "casta" que se han mantenido relativamente estables (en América Latina) durante 300 años. De todos modos, a lo largo de su artículo la autora pone énfasis en la novedad de la raza y en su universalismo ilustrado, que reemplazará en contenido y forma a la casta.

15 Norma Castillo Palma indica esta diferenciación y transformación de las clasificaciones en términos de factores de los cuales dependía la clasificación de una persona en cada momento y lugar: ascendencia, atributos socioculturales y apariencia física. 
lo que hemos llamado el carácter narrativo del paradigma tradicional. Por poner un caso posible: un pardo artesano y miliciano en el Santiago del siglo XVIII no se instalaba en la misma jerarquía que un peón de arría mulato de La Serena, en la misma época, independiente de que ambos fueran libres y que ambos demostraran (con sus partidas de bautismos) ser hijos de dos personas de castas equivalentes, por ejemplo, hijos cada uno de negro esclavo y mestiza. La calidad resultante de ambas personas no tenía necesaria, directa o exclusiva relación con la casta de sus padres ni con el "color" de sus cuerpos. Era necesario ponderar otros varios elementos circunstanciales.

En la península ibérica pasaba algo similar. El estatus legal, la sangre o linaje, el oficio y, finalmente, el color de piel, definían la calidad y por tanto la identidad (de mayor o menor jerarquía) de cada persona. Pero no por esto pensemos que es posible descubrir las clavijas del sistema, al punto de que si logramos determinar las múltiples variables que definían a un individuo, podríamos establecer certeramente la calidad e identidad de una persona. Como ya hemos adelantado, estas variables se conjugaban de un modo siempre local, o como mucho regional. En último término, porque el reconocimiento del otro no dependía de un gran sistema homogéneo en toda la Monarquía católica, ni aún en todos los reinos de las Indias Occidentales: dependía de interacciones y pretensiones concretas, así como se vinculaba (en tanto causa y efecto) con lo que Paula López ha conceptualizado como "regímenes de alteridad” (López, 2017).

Algo hemos adelantado respecto de cómo pudo operar este paradigma, a lo menos en la zona central chilena, refiriendo dos principales autoras que han trabajado el tema. Sin embargo, nos parece que aún es un debate abierto a estudio, por vía del cual creemos que se podrían esclarecer ciertas ideas que circulan en la bibliografía que citamos: la territorialización de lo indígena en la Araucanía histórica, la comprensión de la raza española de manera cerrada y elitista, crecientemente tematizada como "blanca" para fines del siglo XVIII, el abultamiento documental de aquel grupo fluido categorizado como "mestizo" (o perteneciente a las castas), a lo largo y ancho del Reino de Chile, las pretensiones de rigidizar el sistema (también a fines del siglo XVIII, y recordemos la pragmática real sobre matrimonios desiguales), etcétera. Y sin embargo, al estilo de lo señalado por Lorena Rodríguez para el caso de Santa María, en el sur del valle Calchaquí, es probable que aun resolviendo estos parámetros generales nos veamos en la obligación de reconocer la inestabilidad de las clasificaciones raciales con las que pudieron haber sido identificados nuestros antepasados (Rodríguez, 2008).

Quizá el caso de la provincia de Chiloé nos permita poner en cuestión esta actualización local y regional del paradigma racial de Antiguo Régimen. Aunque podríamos hablar latamente sobre aquella provincia austral, nos limitaremos a referir algunas cuestiones fundamentales. Primero, que fue el límite meridional de la cristiandad hasta mediados del siglo XIX. Segundo, que se mantuvo aislada por su lejanía y por la existencia de un país mapuce soberano entre los siglos XVI y XIX, ubicado al norte de Chiloé. Y tercero, lo que nos interesa, que el paradigma racial del que venimos hablando operó de un modo ciertamente peculiar, partiendo por el hecho de que allí se conservó, acaso como en ningún otro lugar de la América hispana, el binarismo racial inaugurado con la conquista. No existe documentación producida en el período monárquico por población oriunda de Chiloé (española o indígena), en la cual se use el concepto "mestizo", como sí se usaba en Santiago y en otras provincias de la misma época, así como, prácticamente, no llegó población de origen africano a aquella región (Araya Espinoza, 2010; Undurraga Schüler, 2012; Catepillán Tessi, 2017, p. 340). ${ }^{16}$

16 Lo que no quiere decir que el concepto no fuera usado, por ejemplo, por funcionarios foráneos, sobre todo en comunicaciones dirigidas a personas o instituciones ubicadas fuera de dicha provincia. 
Aunque la inexistencia del rótulo "mestizo" no implica la inexistencia de personas engendradas por progenitores de distinta calidad o casta, sí nos parece que involucra una manera particularmente conservadora de comprender la raza. Consideremos ahora el recambio de la población de Chiloé y, en específico, la disminución de la población indígena y el aumento de la población "española” entre mediados del siglo XVII y principios del XX. Un proceso que no puede explicarse exclusivamente a partir de procesos migratorios ni de tasas de mortalidad y natalidad diferenciadas (Vázquez de Acuña, 1992). ${ }^{17} \mathrm{Ni}$ aun a partir del asimilacionismo chileno, que hace presencia en Chiloé recién desde 1826.

Junto con una visión purista de la raza como linaje (religioso) que aparece tardíamente, como es el caso de una publicación firmada por Luis Mansilla, de 1911, nos parece que en ciertos sectores de Chiloé se comprendió la raza española de manera hipergámica. Es decir, de manera abierta y absorbente. En otras palabras, los indios de Chiloé, por ejemplo, a principios del siglo XIX podían cambiar su raza. Y lo podían hacer, quizá, casándose o emparejándose con un(a) español(a), adoptando el idioma de Castilla, mudando los nombres o la capilla, integrándose en la milicia, reclamando ascendencias cristianas, en suma, narrándose como españoles. No lo sabemos a ciencia cierta (Catepillán Tessi, 2017, pp. 328-399); ${ }^{18}$ pero sí sabemos que cuando Darwin visitó Chiloé, tal como lo hemos citado al principio de este artículo, en aquella provincia un individuo podía ser español de noble prosapia, no obstante tener una apariencia "enteramente india".

Para ir concluyendo esta sección, nos preguntamos ¿por qué planteamos, en definitiva, que este entramado de sangre, calidad y casta tiene relación con un paradigma racial visualizado desde una perspectiva transtemporal y pluriespacial, como creemos proponerlo acá? En este punto, podemos referir a Aníbal Quijano en su aseveración sobre que la "idea de raza” es, sin lugar a dudas, el más "eficaz instrumento de dominación social inventado en los últimos 500 años", originado, dice este autor, "en el mero comienzo de la formación de América y del capitalismo" (Quijano, 2014, p. 101).

Los más ortodoxos colonialistas, o bien, los más apegados a una visión anglo o francófona de los estudios históricos, dirán que no es lo mismo hablar de las clasificaciones sociales de las sociedades tradicionales, a saber, del Antiguo Régimen o coloniales americanas, cuya raigambre es de origen más bien religioso y estamental, y asociar estas clasificaciones con las designaciones desarrolladas por las ciencias humanas y naturales desde mediados del siglo XVIII, para las cuales la raza se estableció como el gran concepto definitorio de los límites entre las gentes a nivel global y, principalmente, como categoría biológica de la humanidad.

Cuestionamos esta ortodoxia, y cuestionamos la visión anglo y francófona, sin casarnos del todo con Quijano ni con los estudiosos decoloniales. No nos extenderemos en esta ocasión sobre los deslindes de este análisis pormenorizado, y solamente apuntaremos algunas cuestiones que hemos tratado más arriba sobre la raza. Ciertamente, como concepto, "raza" aparece muy tempranamente en la sociedad ibérica (y, en general, en las lenguas europeas), y si bien se puede rastrear a partir de los primeros diccionarios de la Real Academia Española de la Lengua, entendemos que sus significados decimonónicos, y aun dieciochescos, se distancian enormemente tanto de los usos del siglo XV como de los usos posteriores a 1950.

17 En Vázquez de Acuña se puede ver un cuadro general de esta evolución, aunque muy poco problematizado.

18 En Catepillán Tessi podemos observar referencias sobre los modos de la raza en el Chiloé de fines del siglo XVIII y principios del siglo XIX. 
No obstante, no podemos dejar de percibir el nexo necesario entre lo que subsiste en el fondo de la lógica clasificatoria. Ya lo explicita Francisco Bethencourt, a lo largo de su obra Racismos, y es que la lógica racial que sustentó al "racialismo científico" entre 1840 y 1940, aproximadamente, no se separa radicalmente de la jerarquización humana que ya se hacía hacia el siglo XIV en contexto del Mediterráneo, y que se complejizó en el XVI con los viajes europeos de exploración y conquista por todo el orbe.

La raza, que era mancha o traza en un textil o en la "casta" de un animal, que denotaba una impureza o imperfección, y que aplicó a "raza de moro o judío" dentro de la "casta" cristiana, devino en "clase o tipo de humano" hacia el siglo XIX en las teorizaciones imperiales y nacionales, pero sin perder su connotación de separación entre puro/impuro. El gran testimonio de este subtexto de limpieza lo encontramos en el mito del arianismo surgido hacia 1870, y que tuvo su máxima expresión hacia 1920-40. El ario, blanco puro, sin "mixturas" ni "manchas" era quien estaba llamado a llevar la bandera de la civilización moderna, entendida esta como la única manera, la europea, de ser y hacer las cosas (Arre Marfull, 2018, pp. 40-116). Con lo que ya nos estamos adentrando al siguiente punto, el paradigma racial cientifico.

\section{Paradigma racial científico. La raza como base biológica de las naciones (o la configuración de la identidad nacional y las ideologías del mestizaje)}

Los ideales estéticos, sociales y políticos del largo período propuesto para este análisis, presentes en las culturas herederas e influenciadas por Europa, especialmente por Espańa y Portugal hasta mediados del siglo XVIII y por Francia e Inglaterra desde las décadas finales del último siglo colonial, son el resultado de una larga reflexión filosófico-científica y diversas transferencias culturales operadas dentro del complejo escenario imperial global que hemos abordado, hasta el momento de manera reducida y apuntando a la realidad chilena y americana. Sin embargo, dichos ideales no surgieron simplemente por el encuentro entre grupos humanos geográficamente distantes o religiosa y lingüísticamente diferentes, sino que se gestaron, también, de manera local tras una larga historia de relaciones entre múltiples personas y grupos culturalmente cercanos en un espacio geográfico más reducido (dentro de ciertas regiones de Europa, dentro de ciertas regiones de América). He ahí la dialéctica de nuestra propuesta: dar cuenta del "gran proceso", o a lo menos de algunos aspectos de este y, al mismo tiempo, leer dicho proceso a partir de lo local y de nuestra realidad "chilena".

Las configuraciones ideológicas y resultados prácticos de las filosofías estético-políticas que surgieron a inicios de la modernidad, aplicadas a instituciones de tipo imperial, unían principios religiosos monoteístas, como por ejemplo la idea de pueblo elegido, con las formas socioeconómicas del incipiente capitalismo desarrolladas paulatinamente en Europa y en sus espacios de influencia. No es posible entender a cabalidad las posturas racialistas, prácticas racistas y la aplicación de la palabra raza, en definitiva, ya desde mediados del siglo XVIII, si no se tiene en cuenta como trasfondo esta larga genealogía que se remonta, en gran medida, al pasado europeo y del espacio mediterráneo (Todorov, 2000, p. 115 y ss.; Bethencourt, 2015, p. 364 y ss.). ${ }^{19}$

19 Según Tzvetan Todorov, el racialismo es un movimiento de ideas nacido en Europa occidental, cuyo período más importante se ubica desde mediados del siglo XVIII hasta mediados del XX; mientras que racismo es un concepto por un lado más general y por el otro más particular que racialismo, pues puede significar: 1. Comportamiento de odio y menosprecio hacia personas que poseen características físicas 
Entendemos modernidad desde la perspectiva de los estudios históricos ibéricos e iberoamericanos, que sitúan su germen en los procesos de expansionismo mercantilista que tuvieron, en su inicio, una potente impronta religiosa (pueblo elegido por Dios, entidad suprahumana). Es decir, la modernidad sería un largo proceso europeo-mediterráneo que comienza su desarrollo luego de las Cruzadas (siglo XIV) y se va consolidando con la expansión por América, la costa africana y algunos enclaves asiáticos por parte de los "imperios" de Europa. La modernidad sería, además, un relato europeo de sus propios procesos imperialistas, y por tanto, directamente relacionado con la colonialidad, según indican con gran acierto las y los intelectuales del pensamiento decolonial. No hay modernidad sin la colonialidad (tanto del pensamiento como de los cuerpos, podríamos agregar) (Mignolo, 2007, pp. 27-74).

Para ligar el segundo apartado con lo que llevamos revisado sobre el paradigma tradicional de la raza y algunas de las nociones de su campo semántico, vamos a establecer la raza en esta continua red como el concepto clave que reaparece con fuerza en América, luego que sangre, casta y calidad hubieran gestionado las formas de diferenciación social durante los siglos XVI al XVIII. Sin embargo, raza no aparece sola en este entramado de nociones clasificatorias.

Por un lado, se emparenta con la de tipo o variedad humana. En este sentido, la clasificación más difundida, en cuanto a organización humana global, fue la ordenación presentada el año 1735 por el sueco Carlos Linneo (1707-1778) en su obra Systema Naturae. Para Linneo, el ser humano era clasificable dentro de un sistema natural general. Como especie, pertenecía al reino animal, y estaba en la jerarquía superior, aunque muy cerca de los simios, diferenciados de estos por el habla. La humanidad se dividía a su vez en cuatro grupos definidos continentalmente: los blancos (europeos), los amarillos (asiáticos), los rojos (americanos) y los negros (africanos) (Bethencourt, 2015, p. 339).

Poco después, Georges Leclerc, conde de Buffon (1707-1788), fue el que utilizó tal vez por primera vez la palabra raza, aunque también usó naciones o variedades, para organizar racionalmente los tipos humanos del mundo conocido. Publicó en 1749 su Histoire Naturelle, muy influenciado por los escritos de otro francés del siglo anterior, François Bernier (Todorov, 2000, pp. 121-122; West, 2002, p. 99). ${ }^{20}$ Para Buffon, las razas humanas no variaban por su ubicación continental, sino que era preciso analizar el impacto del clima, la alimentación, los hábitos y los procesos migratorios para lograr determinar las diferencias. De esta manera, observó que existían pueblos de características similares en diferentes continentes. Si bien insistía en mezclar elementos psicológicos y físicos en sus clasificaciones, así como las costumbres, para él había una amplia gama de razas definibles y no apoyaba la jerarquía continental (Bethencourt, 2015, p. 341).

Linneo, y sobre todo Buffon, tuvieron un impacto profundo en las investigaciones científicas y en la opinión pública en Europa y América hasta las primeras décadas del siglo XIX. Si bien el segundo amplió y flexibilizó lo establecido por Linneo, por ejemplo, el negar a las razas una localización continental, refutando, además, la idea de que simios y humanos eran cercanos o prácticamente iguales, se planteó en contra del maltrato a los esclavizados y defendió la idea de que todos los seres humanos eran perfectibles, afirmó, no obstante, y como ya era la norma, la supremacía blanca europea (Bethencourt, 2015, p. 345).

distintas al grupo dominante o mayoritario, y/o 2. Ideología (práctica) de una doctrina concerniente a las "razas humanas" (el racialismo).

20 Bernier (1625-1688) fue un viajero y médico francés. Su obra Nouvelle division de la terre par les différentes espèces ou races qui l'habitent, publicada en 1684, es considerada la primera clasificación moderna de las distintas razas humanas. 
Hay una palabra que no podemos dejar pasar a esta altura, y es la idea de nación que utiliza Buffon en sinonimia con raza. Esta relación es esencial para comprender la deriva de las nociones de raza en los discursos políticos, literarios, educativos y científicos de las repúblicas independientes durante el siglo XIX en América. Como explican Tomás Pérez Vejo y Pablo Yankelevich, la imbricación entre nación y raza con una potente fuerza telúrica, esencia del romanticismo herderiano, tendrá una influencia radical en América y, asimismo, en Chile (Dager Alva, 2002; Pérez y Yankelevich, 2018, p. 11). ${ }^{21}$ De hecho, en la conocida polémica sobre el método historiográfico apropiado para usar con el fin de conocer y enseñar la historia de Chile, dada entre el ya célebre Andrés Bello y los jóvenes José Victorino Lastarria y Jacinto Chacón, entre 1844 y 1848 (precisamente en el tiempo en que V. F. López escribía su Manual), Bello le reclamaba a estos intelectuales y profesores la fuerte influencia de Herder en sus propuestas, que los jóvenes defendían como un método filosófico mejor y más "moderno" que el "anticuado" método narrativo propugnado por el maestro (Dager Alva, 2002).

A decir verdad, el método de Bello era mucho más actual y moderno en cuanto a su racionalidad ilustrada. La exhaustividad en la revisión documental que Bello defendía derivaba de su entrenamiento filológico desarrollado durante casi dos décadas en Inglaterra, mientras que los jóvenes enarbolaban argumentos de un autor que había publicado casi sesenta ańos antes. La pregunta que surge es ¿cómo y cuál había sido el impacto de Herder y la "extraña deriva" de la Ilustración, como lo fue el romanticismo, en relación a los paradigmas raciales en Chile?

Detengámonos brevemente en otras cuestiones antes de intentar responder esta pregunta siguiendo el estudio de las lógicas raciales de la nación, tema que tanto dio que hablar a los publicistas y hombres de Estado durante décadas.

El XIX fue el siglo de la ampliación del racialismo, entendido como la diversa gama de discursos que tienen como eje, o como uno de sus ejes fundamentales, a la raza. El respaldo de la ciencia empírica, que gozaba cada vez de mayores seguidores, ayudó a profundizar las investigaciones y reflexiones sobre las razas humanas, en un afán de lograr comprender, contener y controlar el mundo y sus gentes a partir de esta forma de conocimiento, el racialismo, ya legitimada en los imperios capitalistas.

Las teorías sobre las razas humanas se diversificaron en sus métodos de comprobación y aplicaciones políticas, surgiendo en este proceso la antropología, y luego la etnología, como ciencias específicas, separadas de la Historia Natural que había albergado el estudio de las razas desde el siglo XVII (West, 2002, p. 100). ${ }^{22}$ En este marco de aparición de nuevas ciencias y nuevos métodos, en América proliferaron las expediciones y viajes de todo tipo, muchos de ellos con una clara misión etnográfica y naturalista, que tenían como correlato la presión económica

21 Johann Gottfried Herder (1744-1803), filósofo, teólogo y crítico literario alemán. Desarrolla la idea del Volksgeist (espíritu del pueblo), que se expresa en la lengua y la literatura de una nación. La filosofía de Herder tuvo gran influencia en el contexto francés y también en Chile, a través de Francia. Según ellos mismos confiesan, José Victorino Lastarria y varios de sus contemporáneos leyeron con entusiasmo las Ideas sobre la filosofía de la historia de la humanidad del filósofo alemán, en la traducción de Edgar Quinet.

$22 \mathrm{La}$ antropología fue fundamentada principalmente por los postulados del alemán Johann Friedrich Blumenbach (1752-1840), quien utilizó criterios semejantes a los de Linneo y particularmente similares a los de Buffon para establecer las diferencias humanas. A semejanza de los estudiosos anteriores, con un afán objetivo Blumenbach jerarquizó igualmente a los numerosos pueblos en sus descripciones de las razas, estableciendo como modelo estético al hombre griego, al basarse en las esculturas y descripciones del mundo clásico. 
y política de los poderes imperiales. Entre dichos viajeros, y viajeras, aunque estas en menor número (Sandoval Candia y Arre Marfull, 2018), es donde aparecen Von Tschudi y Darwin haciendo sus observaciones "objetivas" en relación a la raza, en este caso, la biológica y "verdadera” raza de los habitantes de los parajes americanos que visitaron.

Pero esta forma de ver la raza no es, ni remotamente, la única. Como ya hemos indicado, la raza se transformaría en el concepto más popular de organización de la diversidad humana, siendo a su vez, una noción tremendamente difícil de asir (por su variabilidad), pero muy fácil de comprender.

Con todo, es importante agregar que las normas estéticas culturalmente determinadas han estado profundamente presentes en las teorías de las razas, y muchas veces son estas las que priman en las observaciones etnológicas. Así, los valores locales de la Europa germánica comenzaron a fijarse como universales en nombre de una objetividad científica a la par que se desarrollaba la Historia Natural y sus derivados. La belleza funcionó como uno de los principios de jerarquía entre las razas, una consideración, esta, claramente subjetiva, pero aplicada como objetiva. A modo de ejemplo, tenemos al famoso filósofo ilustrado Immanuel Kant quien, como otros "sabios" contemporáneos y posteriores a él, indicó que las razas más bellas, y las más capaces de producir belleza y, por lo tanto, superiores, eran las blancas europeas (Kant, 1764). No se trataba simplemente de describir las diferencias humanas. Se trataba de definirlas, ciertamente, en relación a un patrón universal (Lepe-Carrión, 2012, pp. 176-213). ${ }^{23}$

Los valores estéticos se transforman así en valores morales, pues la belleza entra en diálogo directo con el intelecto y la conducta estimada como superior. En sus estudios, David Theo Goldberg ha acuñado un término que es operativo para este aspecto profundamente estético de las razas, y es la idea de pobreza racial (racial poverty), en consonancia con las sociedades mercantiles donde las teorías de las razas comenzaron a expandirse. La belleza de las razas, o las razas consideradas bellas desde la visión eurocéntrica, tenían así un bien superior que ofrecer al mercado (Goldberg, 2002).

Las y los investigadores concuerdan que es hacia la década de 1840 que comenzaba la "era" del racialismo científico, muy ligado extrańa o curiosamente, si seguimos a Pérez Vejo y Yankelevich, a la naciente doctrina del nacionalismo (Bethencourt, 2015, pp. 417 y ss.; Hering Torres, Schaub y Sebastiani, 2016, p. 25). ${ }^{24}$ Curiosa ligazón, ya que en el XIX la raza se pretendía entender como un concepto científico, biológico, racional y objetivo, mientras que la nación obedecía más bien a directrices políticas, históricas y narrativas (genealógicas), de marcado localismo. Pero si observamos el devenir de raza y sus nociones hermanas (casta, sangre, calidad) vemos que la política (y con ello las jerarquías sociales, las diferencias lingüísticas y religiosas) es el espacio en donde se han gestado, completado y transformado estos conceptos. Podríamos llegar a afirmar que el paradigma tradicional de las razas, representado en América en las castas

23 En Lepe-Carrión encontramos un interesante análisis sobre el racismo de Kant.

24 Jean-Frédéric Schaub, Silvia Sebastiani y Max Hering Torres discuten esta denominación de "raci(ali) smo científico", aludiendo que las prácticas discriminatorias existían desde antes, y que además, la ciencia no fue un invento del siglo XIX. Sin embargo, coincidimos con la denominación tradicional presentada por Bethencourt, puesto que, si bien la práctica científica es antigua, no puede desdeñarse el hecho de que el racionalismo y el positivismo decimonónico unidos a los avances tecnológicos y expansión mundial generaron una nueva, o nuevas maneras de enfrentar la realidad natural y humana. Por otra parte, en el siglo XIX surgen una serie de prácticas científicas con denominación propia y metodologías y objetivos particulares. 
coloniales, se traspasó a los idearios nacionales decimonónicos, que a su vez se sustentaron en conceptos del paradigma científico del desarrollo de las razas dentro de la Historia Natural. Es, tentativamente, en el concepto de nación-igual-raza que tanto lo narrativo como lo biológico se encuentran, y desde ahí podríamos entender la deriva romántica herderiana de las doctrinas nacionales que permearían hasta el siglo XX en cuanto a su contenido racial.

Sin que neguemos la diferencia entre las razones teo-lógica (tradicional) y ego-lógica (moderna), en palabras de Walter Mignolo, o entre fe y razón, lo que intentamos explicitar es que, aun existiendo dos paradigmas, en lo que respecta a la raza y su campo semántico, nos parece que existiría una relación de continuidad entre ambas lógicas, aunque derivada de sus existencias históricas, o si se quiere, de su encuentro de hecho en la cultura y en los cuerpos.

Tras la traducción al inglés de Los Vedas a mediados del siglo XIX, que referían migraciones de pueblos pastoriles llamados arya hacia la India, así como el choque entre estos pueblos nobles invasores de "tez clara" y las "oscuras" poblaciones locales, consideradas bárbaras, se reinstala la idea mítica de encontrar un fundamento histórico a la supremacía blanca (Lepe-Carrión, 2012, pp. 93-106, Bethencourt, 2015, pp. 388-391). ${ }^{25}$ Sin embargo, este casi legendario antecedente reafirmó los argumentos de diversos científicos y filólogos para descubrir en todas las grandes civilizaciones un origen común ario (blanco). Si bien Kant, ya en 1775, se refería a las poblaciones blancas en el Tíbet y en el norte de la India, fue el filósofo francés Joseph Arthur de Gobineau (1816-1882) quien cristalizaría el mito ario en su obra Essai sur l'inégalité des races humaines (1855), argumentando que estos eran los antepasados de los blancos de todo el mundo y la base de la desigualdad social dentro todas las grandes civilizaciones, idea que rápidamente adaptó nuestro Vicente Fidel López, cuando ya se había convertido en uno de los más célebres historiadores y novelistas argentinos, en su obra Les races aryennes du Pérou. Leur langue, leur religion, leur histoire (1871).

El mito ario se difundió inicialmente en Alemania y Estados Unidos, donde fue reinterpretado localmente, coincidiendo en uno con el pangermanismo y la imaginación de la raza teutonagermana, y en el otro, con la concepción de la nación blanca (luego sintetizada en la expresión $\left.W A S P^{26}\right)$ en oposición absoluta a los negros, indígenas y católicos de América. La postura principal de Gobineau era su concepción sobre la desigualdad esencial y natural. Estaba decidido a contraponerse a las nuevas ideas sobre la igualdad social propiciadas por el comunismo y el socialismo. En este sentido, su postura era elitista o aristocrática y despreciaba profundamente la idea de promoción por el mérito. De esa manera, lo ario-blanco encajaba perfectamente con su filosofía, pues este grupo se instalaba en la historia humana como el contenedor de los valores superiores: eran la élite del mundo, en todas las civilizaciones conocidas.

Es importante destacar la filiación de este autor con las ideas de la degeneración de las razas producto de la miscegenación, ideas que ya se repetían en muchas teorías anteriores, y que van a entroncar con las propuestas eugenésicas popularizadas en la última década del siglo XIX y las primeras tres décadas del siglo XX (Soutullo, 1997; De Matos, 2006; Pérez Vejo y Yankelevich, 2018, p. 47). ${ }^{27}$

25 Consultar en Lepe-Carrión sobre la genealogía epistemológica del concepto de bárbaro y su aplicación en América.

26 White Anglo-Saxon Protestant.

27 Los 10 capítulos, escritos por diferentes autores y autoras, del compilatorio de Pérez Vejo y Yankelevich, entregan contundentes antecedentes sobre este paso del siglo XIX al XX y las profundas políticas eugenésicas antiindios y antinegros, generadas en Cuba, Brasil, Argentina, Bolivia, Centroamérica, Colombia y México. 
En estos años ya se cuenta con una muy popularizada y extendida literatura racialista y algunas no esencialmente racialistas, pero que operan como sustento para los autores que buscan destacar la raza como centro de reflexión. No podemos enumerar en este espacio tantas obras de referencia para el desarrollo de las ciencias y de las políticas públicas de Chile en aquel entonces, pero basta con señalar que Darwin, a quien mencionamos al inicio, y su primo intelectual en las ciencias humanas, Herbert Spencer, van a ser dos pilares fundamentales del racialismo y racismo chileno, el cual podemos ejemplificar con la ya reconocida obra del médico Nicolás Palacios, Raza chilena: libro escrito por un chileno y para los chilenos (1904). Con esta referencia, nos surge la pregunta ¿ser "chileno" era pertenecer a una raza o a una nación? ¿Cuál era la similitud o distancia entre uno y otro concepto?

Llegados a este punto, nos parece necesario volcarnos brevemente a los vocabularios políticos con los cuales se comenzó a construir la nación en Chile. La nación, hablando de definiciones teóricas en los albores liberales de esta república sudamericana, era ni más ni menos que "la única forma de legitimación del ejercicio del poder" (Pérez Vejo, 2003, pp. 280-283). El problema es que la voz "nación" no ha denominado siempre a un mismo sujeto (Chiaramonte, 2004, p. 52). A principios del siglo XIX, y afín al iusnaturalismo dominante entre los intelectuales y políticos americanos de entonces, la nación era comprendida sobre todo como "un conjunto humano unido por un mismo gobierno y leyes" (Chiaramonte, 2004, p. 35), es decir, un conjunto de ciudadanos, hasta cierto punto desligada de los sentidos más o menos culturales, raciales y territoriales a los cuales el concepto nación estaba asociado, incluso etimológicamente (Pérez Vejo, 2003, pp. 279-80).

Esta identidad entre nacionalidad y ciudadanía, consagrada en la Constitución de 1833 (capítulo IV, "De los chilenos", pp. 5-7), también late en aquellos famosos decretos de O'Higgins que ordenaban la prohibición de toda denominación distinta a la de chileno para los ciudadanos nacionales (Decreto del 3 de junio de 1818), o la eliminación del tributo de la población india y el reconocimiento de su ciudadanía (Decreto del 4 de marzo de 1819). Y sin embargo, como es de público conocimiento, la ciudadanía en las repúblicas latinoamericanas se montó sobre el vecinazgo español (Guerra, 1999, pp. 42-43). Lo que puede ayudarnos a comprender los inicios del asimilacionismo chileno y la territorialización, por ejemplo, en la Araucanía histórica, de todo discurso posible sobre lo indígena en el Chile de los siglos XIX y XX.

La pregunta sobre cómo eran y cómo debian ser aquellos ciudadanos que conformaban la nación chilena nos parece, sin embargo, que se volverá central en ańos posteriores. Recién a partir de la década de 1840, pero con mayor claridad luego de la Guerra del Pacífico, comienza a desarrollarse la "racialización" de la nación, o la definición de la nación ya no solo como categoría político-institucional, sino también como "comunidad cultural, con historias, tradiciones y mitos comunes" (Cid y Torres, 2009, p. 42). Nos parece que será en relación a esta forma de comprender la nación que se desarrollarán a lo largo y ancho de toda la América hispánica diversas ideologías del mestizaje, que en parte retomarán el paradigma racial de Antiguo Régimen, y su vocabulario (p.e., la categoría "mestizo"), y en parte (quizá la más visible), el paradigma racial científico e ilustrado.

El contraste entre la raza chilena de Nicolás Palacios (o la raza cósmica de Vasconcelos) y las ideas de Vicente Fidel López sobre la "raza del campo" y la "raza de la ciudad" (dualismo irreconciliable, imposibilidad de mestizaje) podría darnos el tono del desplazamiento operado por las intelectualidades y los políticos latinoamericanos en los años que hemos señalado. En síntesis, la idea de nación expresada racionalmente como vínculo legal no permeó la aplicación 
real del concepto, sino que se terminó mixturando con concepciones raciales tradicionales o propuestas "científicas", lo que generó derivas múltiples, aunque emparentadas bajo el amplio paraguas de la raza.

Retomando lo dicho hasta ahora, y para puntualizar ciertas cuestiones, hemos expuesto más arriba que Chile, así como los demás países americanos, contuvieron dentro de sus regiones históricas cantidades variables de habitantes de tres principales grupos continentales, que divergieron en sus lenguas, apariencias físicas y costumbres: indígenas americanos (indios), africanos subsaharianos (negros) y europeos peninsulares y otros (blancos o españoles, portugueses, etc.). Muy tempranamente se llamó mestizo al vástago de la mixtura (más biológica o más cultural) entre indios y españoles. No era un vocablo nuevo en las lenguas ibéricas, y se utilizaba antes para indicar la mezcla de dos componentes desiguales en cuanto a uniones entre seres humanos. Claramente indios y españoles eran, por muchas razones, desiguales. Pero no lo eran, solo o tan solo por cuestiones de contextura física, color de piel, tipo de cabello. Las diferencias radicaban en otros varios indicadores de tipo cultural, como nos lo han contado extensa y detalladamente Carmen Bernand y Serge Gruzinsky (2005).

Sin embargo, el vocablo rápidamente popularizado en América para nombrar a los hijos de europeos y africanos negros no fue mestizo, sino mulato o moro, términos que ya se venían usando en la península ibérica. Mulato refería a una concepción zoológica de la mezcla, mientras que moro, a una visión religioso-cultural. El concepto zoológico se perpetuaría en América, junto a otras voces como zambo, para referir a las mezclas de cualquiera con africano (Araya Espinoza, 2010, p. 347). Moreno (de moro) se transformó con el tiempo en el eufemismo de negro para denotar una condición, en general, de libre. Pardo (color marrón) era normalmente el eufemismo de mulato libre.

Pero más allá de estas puntualizaciones, fue el mestizo, el vástago indoespañol-blanco, quien concentró la imaginación de las concepciones racial-nacional durante los siglos XIX y XX americanos. En suma, porque fue gestionándose una idea del mestizaje como un proceso capaz de renovar al indio, lo cual indudablemente desembocará en el desarrollo latinoamericano de la eugenesia (Sánchez, 2015) y de los indigenismos, pero que también estaba en concordancia con los ideales de lo civilizado versus lo bárbaro-salvaje, o de la oposición entre el futuro y el pasado que sintetizó Domingo Faustino Sarmiento en su Facundo, libro que escribió en Santiago durante el mismo tiempo en que V. F. López, su compańero de exilio, escribía el Manual de Istoria de Chile ya citado.

No sería abusivo, por lo mismo, pensar la construcción de las naciones en la América hispana como un retorno al binarismo racial con que originalmente se pensaron los reinos en las Indias Occidentales: el discurso decimonónico (y hasta mediados del XX) va a ser implacable con lo negro, tanto en la práctica como en la letra. La lucha por desarraigar al negro de la memoria, el color y las representaciones de las naciones republicanas se hará sentir fuertemente en lugares en los cuales era muy difícil desentenderse del pasado (y presente) esclavista, así como también en aquellos lugares en los cuales se instaló con mayor facilidad la creencia de que nunca habian existido negros, como en Chile, Argentina, Costa Rica o México (Cáceres, 2000; Del Río Ortiz, 2010; Funes, 2018; Stavenhagen, 2018).

Precisamente, lo que intentarán solucionar los artífices de la nación será esta dicotomía racial entre dos grupos concebidos como separados y distantes por todo: unos que viven en ciudades y hablan el español, que siguen las modas europeas, que tienen ciencia y escuelas; otros que 
no usan esos vestidos, no hablan español, no tienen libros, ciencia ni escuelas, y más aún, que viven en "campos desiertos" (López, 1845, pp. 33-36). ${ }^{28}$ Sin duda alguna, esta oposición sirvió a la justificación de aquellas campańas militares que, de manera muy clara, sus autores denominaron "conquista del desierto" (Argentina) y "pacificación de la Araucanía" (Chile). Aunque también es probable que encontremos trazas de estas nociones raciales en los discursos chilenos sobre la guerra de invasión a Perú y Bolivia (McEvoy, 2011).

La propuesta de cómo entendemos el paradigma racial científico y cómo habría operado en Chile, para ir concluyendo nuestra exposición en este punto, aunque lejos de cerrar la discusión, tiene relación con plantear la idea de clasificación universal de las diferencias humanas o la categorización de los humanos a partir de sus características físicas, que emergió con fuerza a fines del siglo XVIII. Una clasificación íntimamente vinculada al desarrollo de la taxonomía y la biología occidental, que se imbricó con las necesidades políticas de las naciones en formación y que desembocó en la propuesta de que existían, verdaderamente, tipos humanos operando como especies distintas y valoradas de desiguales maneras.

Dicho paradigma científico comenzó a ser desmontado en el ámbito científico occidental lentamente alrededor de la década del veinte (Beltrán, Wade, Restrepo y Santos, 2017, p. 27), aunque recién tuvo su expresión oficial y "universal” en 1978 con la Declaración sobre la Raza y los Prejuicios Raciales de la Unesco. Es importante apuntar que si bien este acuerdo conjunto indicaba que "todos los seres humanos pertenecen a la misma especie y tienen el mismo origen, nacen iguales en dignidad y derechos y todos forman parte integrante de la humanidad", en concreto, creemos que tanto el paradigma tradicional narrativo como el científico subsisten, incluso hasta hoy, mixturados con idearios de raíz romántica herderiana que naturalizan las características humanas y estigmatizan elementos culturales a partir de las manifestaciones corporales estereotipadas. Nos parece una prueba clara de esto el hecho de que el mestizaje, como proyecto político, sea reivindicado en Chile tanto por funcionarios del Estado como por grupos indígenas, por nacionalistas y por críticos del nacionalismo: la maleabilidad y los sustratos de la raza permiten que confluyan en una misma voz usos antagónicos.

\section{Conclusión: fantasías genómicas y paradigma racial mapuce}

La trayectoria de la raza, que cruza los caminos de los conceptos de casta, sangre y calidad, nación y tipos de la especie humana, se ha reconstruido en las páginas precedentes dentro de las posibilidades de este artículo, con el fin de dar cuenta del nomadismo y multifuncionalismo de este concepto para iluminar nuestra reflexión sobre los dos paradigmas raciales que hemos visualizado en este largo recorrido temporal, manifiestos, según nuestra propuesta, aún hasta el día de hoy en Chile.

Para concluir este artículo, realizaremos un contrapunto, en primer lugar, con la divulgación y recepción de la genómica contemporánea, y en segundo lugar, con una forma radicalmente distinta de la comprensión y la gestión de las diferencias humanas: el paradigma racial mapuce. $\mathrm{O}$, al menos, intentaremos dar un bosquejo de lo que podría pensarse como tal, sobre

28 Y no nos parece redundante aclarar el uso que V. F. López, así como sus contemporáneos, hace del "desierto". En síntesis, nos parece que define el desierto, en términos políticos y raciales, como todo espacio (incluso habitado) no intervenido ni dominado por el "hombre civilizado". Es evidente que late esta misma definición en el nombre eufemístico con que se conoce el inicio del genocidio mapuce en Argentina ("conquista del desierto"). 
todo para los siglos XVIII y XIX, es decir, el período anterior a la invasión chileno-argentina al país mapuce. Nos parece que este contrapunto nos permitirá apreciar con mucha nitidez la actualidad e historicidad de los paradigmas raciales tradicional y científico, de los que ya hemos dado cuenta.

Respecto de la primera cuestión, aclaramos que seguimos de cerca la propuesta de Carlos López Beltrán, Peter Wade, Eduardo Restrepo y Ricardo Ventura Santos (2017). Consideramos que, a pesar de que la genética contemporánea haya probado la inexistencia de razas biológicas como eran pensadas hasta inicios del siglo XX, existen elementos de la práctica genómica que sirven al reciclaje de antiguas nociones raciales. Si nos concentramos en la divulgación y recepción de estos estudios, nos encontramos con que, de hecho, pueden reforzar ciertas nociones raciales, aunque basadas en la ancestría entendida como denominadora de grupos humanos separados por continentes de origen. Fundamentalmente, porque las categorías utilizadas en la investigación genética no son conceptos neutros. Al contrario, se trata de conceptos cargados de significados históricos y, por lo tanto, conceptos variables y disputados.

En otros términos, nos parece que no se puede eludir el hecho de que, para el público general, la genómica actualiza el debate y el uso de conceptos como raza y nación (Beltrán, Wade, Restrepo y Santos, 2017, pp. 23-24). Y más aún, actualiza sus usos con (posibles) nuevos contenidos: la reducción de las diferencias entre los individuos a la "sangre" que portan, en concreto el ADN ("genetización”); la reificación de los genes, transformados en fuerzas determinantes ("fetichismo genético"); la construcción de vínculos sociales a partir de una supuesta base biológica ("biosociabilidad"); incluso, el uso de rasgos genéticos para definir quién pertenece a un Estado o a una identidad indígena (The New York Times, 1 febrero 2019) ${ }^{29}$ y qué derechos le corresponden (“ciudadanía biológica”) (Beltrán, Wade, Restrepo y Santos, 2017, pp. 36-38).

Por otro lado, si nos concentramos en la práctica científica, también podemos encontrar algunos "elementos racializadores" en la investigación genómica contemporánea. Dentro de estas nos interesa destacar dos: 1) el uso de estrategias de muestreo a partir de "poblaciones" determinadas, consideradas como "puras" y por tanto adoptadas como referente para medir la ancestralidad de "poblaciones 'mezcladas' (admixed)" (Beltrán, Wade, Restrepo y Santos, 2017, p. 31); y 2) la preocupación por el estudio de la genética de la nación o, en otras palabras, el esfuerzo por connotar genéticamente la idea de nación (Beltrán, Wade, Restrepo y Santos, 2017, p. 35; Berríos del Solar, 2017). ${ }^{30}$

Siguiendo la línea de López Beltrán y compañía, podríamos preguntarnos respecto del ejercicio de los genetistas en Chile y sus publicaciones: ¿cómo es que usan el concepto raza-ADN? Y ¿Cómo articulan sus investigaciones con las identidades colectivas, partiendo por la identidad de nación? Estas preguntas dan para una exposición mayor que las conclusiones de un artículo como el que estamos cerrando. De todos modos, intentemos responderla brevemente reflexionando sobre algunas publicaciones divulgativas vinculadas a los principales proyectos genómicos que actualmente se están desarrollando en Chile. ${ }^{31}$

29 Ver, por ejemplo, el caso de la senadora estadounidense Elizabeth Warren, que utilizó un test de ADN para probar su ancestría indígena en una larga disputa con D. Trump. El último evento de esta disputa, hasta donde sabemos, corresponde a las disculpas que E. Warren ofreció a la nación Cherokee por su proceder.

30 El estudio sobre el ADN de los chilenos de Soledad Berríos del Solar es uno de estos trabajos que podría ser leído como una "genetización" de la nacionalidad en Chile.

31 Proyectos “Chile secuencia a Chile: 1000 Genomas", del Centro de regulación del genoma, el Centro de modelamiento matemático, el Centro avanzado de enfermedades crónicas, el Centro de gerociencia, 
Para no generar confusión diremos que, pese a la marginalización de la palabra raza en las ciencias sociales y humanas desde la década del setenta, por su contenido jerarquizante y discriminatorio, las ciencias biológicas siguieron utilizándola para definir los grandes grupos continentales que comparten ciertas características biológicas. Por otra parte, el concepto raza sigue siendo de aplicación usual en contextos cotidianos no científicos. La raza, de esta manera, sigue funcionando no obstante ser vista como "políticamente incorrecta" y estar cargada de anterioridades que nos recuerdan toda aquella trayectoria referida extensamente más arriba, así como el sinfín de prácticas discriminatorias y de exterminio propiciadas por diversos Estados nacionales y fuerzas imperiales, incluso, hasta el día de hoy. ${ }^{32}$

Volviendo a los estudios del genoma humano para Chile, como una suerte de re-racialización de las naciones y re-nacionalización de las ciencias, nos percatamos de que, de alguna manera, los dos paradigmas raciales consignados en este artículo (más su derivado romántico-nacional) han seguido funcionando en el siglo XXI, toda vez que se está haciendo un esfuerzo por descubrir y desentramar el llamado "genoma chileno". ¿No es esto acaso resituar bajo el alero de lo nacional (conjunto supuestamente homogéneo de personas que comparten una historia, una lengua y costumbres) la biología de los habitantes que, por razones históricas (es decir accidentales), llegaron a nacer, interactuar y desarrollarse dentro de este territorio llamado "Chile"? Uno de los argumentos, y que daría para una larga discusión, es que la importancia de descubrir la ancestralidad "chilena" tiene relación con la posibilidad de saber la predisposición de unos y otros grupos continentales a ciertas enfermedades hereditarias y, por ende, que pudieran afectar más o menos a los chilenos (Berríos del Solar, 2017, p. 12).

Es un lugar común, en las definiciones y divulgación de estos proyectos, la afirmación de pretender explícitamente desmontar los prejuicios raciales (El Mostrador, 13 septiembre 2016). Sin embargo, la manera en que se presentan estas investigaciones científicas puede llevar a reforzar o reinterpretar antiguos prejuicios según los cuales existen vínculos ineludibles entre determinadas enfermedades o "tachas" y determinados grupos humanos (Santana Pérez, 2017) ${ }^{33}$ y, en suma, servir de actualización a los paradigmas raciales tradicional y científico, a través de los cuales buena parte de la población sigue comprendiendo las diferencias humanas.

Con lo anterior en ningún caso estamos asumiendo una causa en contra de los estudios genéticos. Como historiadores y estudiosos de las culturas, nos entusiasma todo medio que nos permita conocer algo más de la humanidad, presente y pasada. Nos parece, eso sí, que la investigación genética no puede realizarse ni divulgarse pretendiendo que sus datos no tienen cargas ideológicas específicas, ni obviando la responsabilidad social de sus investigaciones, toda vez que pueden servir a los fines más insospechados.

Por último, y por no dilatar aún más este extenso artículo, nos referiremos brevemente a la posibilidad de que, durante varios siglos, coexistiera (en términos geográficos) un tercer paradigma racial, junto con los dos que hemos abordado: el paradigma racial mapuce. $\mathrm{O}$ al

salud mental y metabolismo, y el Instituto milenio de biología integrativa (www.1000genomas.cl) y "Chile Genómico", de la Universidad de Chile (www.chilegenomico.cl/).

32 La guerra "antiterrorista" Occidente/Medio Oriente no se puede entender solo por un asunto de petróleo. Por otra parte, tanto D. Trump como J. Bolsonaro son una prueba fehaciente del "renacimiento" del racismo.

33 Por ejemplo, las ideas que circulan sobre el aumento del VIH en Chile producto de la inmigración afrovenezolana, afrocolombiana y haitiana, o los tan arraigados estereotipos acerca de que los indios son propensos al alcoholismo o los negros a enfermedades venéreas por su conducta "lasciva", etcétera. 
menos, el paradigma racial que, aparentemente, la población mapuce de la Araucanía histórica implementó para las diferencias sociales y humanas durante un extenso arco, que nos podría remitir a la expansión meridional del Tawantinsuyo, pero que ciertamente ha sido probado (mediante documentación española) en su relación con los europeos al menos durante los siglos XVI, XVII, XVIII y XIX. Es decir, durante el período en que aquella población mapuce supo sostener su soberanía.

Y, aquí, aclaramos que seguimos la propuesta de Guillaume Boccara (1999, 2007). Si bien no es el primero ni el único en preguntarse por la historia del pueblo mapuce -y así podemos consultar publicaciones señeras como el iEscucha winka!, que recientemente ha sido reeditado por la "Comunidad de Historia Mapuche" o el capítulo III de Guerra y sociedad (Jara, 1971)-, sí nos parece que es Boccara quien introduce un elemento central: la identidad mapuce se produjo en el encuentro con los españoles. Al punto de que recién en el siglo XVIII la población de la Araucanía histórica (entre los ríos Biobío y Toltén) comenzó a denominarse de esta manera, en concordancia con una serie de importantes transformaciones relacionadas con "la concentración sociopolítica, la transformación de la lógica económica" y la "unificación del sentimiento identitario" (Boccara, 2007, p. 21).

Estos asuntos están sujetos todavía a discusión. Lo que nos interesa destacar es que el mecanismo que estuvo a la base de este proceso fue la apertura hacia el otro, mediando una "lógica caníbal" que hacía posible captar la diferencia, y más aún, que hacía necesario captarla para completar la propia identidad. Una lógica caníbal, por último, que si bien sirve de metáfora para comprender lo que nos ha parecido prudente denominar como "paradigma racial $m a-$ puce", también se realizó en términos concretos, aunque de manera ritual (no olvidemos el corazón de Pedro de Valdivia) (Boccara, 2007; Menard, 2010).

Ciertamente, a un mapuce de 1840, pongamos por caso, no le preocupaba usar ropa militar chilena, ni tampoco vajilla foránea, así como no le preocupaba leer ni escribir cartas (Guevara y Mañkelef, 2002, p. 31 y ss.), ${ }^{34}$ porque en el uso que haría de aquella ropa, de aquella vajilla y de aquella tecnología, se transformarían en objetos y tecnologías mapuce. Mucho menos le complicaba tener hijos con una mujer extranjera: los hijos que fueran de su generación serían así mismo mapuce, con independencia de sus variantes físicas. Es por esto mismo que franceses, españoles, argentinos o chilenos pudieron transformarse en mapuce al abrigo del mapuzugun y los makuñ tejidos en la Araucanía histórica durante aquellos siglos. La condición que posibilitaba esta forma de pensar la diferencia era, ciertamente, la soberanía. Y nos parece que sería una buena hipótesis, para trabajar, la relación entre la desaparición o transformación de este paradigma y la conquista chilena y argentina del país mapuce o, propiamente hablando, del corazón del Wajmapu (Foerster, 2004, caps. 3 y 4). ${ }^{35}$

No es mucho lo que podemos adelantar acá. Y sin embargo, creemos que la historia de Ñancu o el mestizo Alejo, del siglo XVII, ilustra bien el punto. Del mismo modo que lo hace el caso del mapuce de origen francés con quien se encontró Ignacio Domeyko en 1845 (Domeyko, 2009, p. 133), el apodo de infancia de Manuel Mańkilef (Manuel Manquilef, 1911, p. 6) ${ }^{36}$ y, así como su madre Trinidad González, la larga y profunda historia de los y las cautivas a lo

34 Ver, por ejemplo, la biografía de Lorenzo Kolvpi.

35 Es decir, con las consecuencias de aquellas campañas militares: exterminio, saqueo y empobrecimiento, aislamiento y reducción, minorización, trauma, etcétera.

36 Según cuenta Mañkilef, sus compañeros de infancia lo apodaban ceuntu (“el que se vuelve gente”), en alusión a su madre chilena y al hecho de que era tan mapuce como el que más. 
largo y ancho del Wajmapu, o el país mapuce. No por nada a Claudio Gay, imbuido del paradigma racial científico, le parecía imposible "determinar exactamente el carácter fisonómico de los primeros habitantes de la Araucanía” (Gay, 2018, p. 15). Ningún mapuce, previo a la década de 1880, veía un valor superior en aquel "carácter fisonómico" original, y puede que haya sido todo lo contrario (ver p.e., Bello, 2011, pp. 201-207). La "mapuchización” del otro implica necesariamente una transformación del yo. Y esta es precisamente la modalidad que, aparentemente, el inca Pedro Bohórquez quiso implementar a mediados del siglo XVII en el Calchaquí, por influjo de su experiencia con los rece-mapuce en las inmediaciones de Valdivia y, probablemente, por influjo de su compañera, oriunda del país mapuce, que era tenida por maci, y que actuó como una líder de la última guerra calchaquí (Piossek, 1976, p. 177; Lorandi, 1997). ${ }^{37}$

Por último, consideramos que, así como este paradigma racial puede apreciarse en los ejemplos señalados, podría pesquisarse en las relaciones interétnicas en las fronteras sur y oriental del país mapuce. Es decir, en las pampas bonaerenes y Patagonia oriental, cuya "mapuchización" ha servido como argumento del genocidio operado por la República Argentina. Pero también en el sur de Chiloé, donde se encontró población mapuce y población chona, y de cuyas relaciones, como ha señalado con justa razón David Núnez (2018), la mixtura de toponimia mapuce y chona es un buen indicio.

Resta todavía mucho por estudiar respecto de este paradigma, cuya existencia habría aún que probar y que, nos parece, sería preciso de abordar despegándose momentáneamente del concepto champuria con que, hoy por hoy, los mapuce denominan lo mezclado. Un concepto, por lo demás, relativamente reciente, de clarísimo origen hispano y probablemente incorporado al léxico mapuce luego de la conquista militar de fines del siglo XIX (RAE, 1832, 2014; Román, 1908, p. 11; Corominas, 1984, pp. 331-332). ${ }^{38}$ Del mismo modo, sería pertinente abordar el registro de otros conceptos para denominar las distintas genealogías y las diferencias humanas, como puede ser el uso metafórico de la palabra mojfuñ, que literalmente significa "sangre" (Moesbach, 1936, pp. 76 y 270), ${ }^{39}$ y como el concepto más conocido wigka(ce), castellanizado como "huinca”, que hoy se utiliza para denominar genéricamente al extranjero con cierta nota despectiva.

37 Sobre el inca Pedro Bohórquez se puede leer abundante bibliografía. Remitimos a dos libros: el de Teresa Piossek y el de Ana María Lorandi. Hasta donde sabemos, ningún documento registró el nombre de la compañera de Pedro Bohórquez, a pesar de que sí se registró su procedencia del país mapuce, aunque insistentemente se la sindicó como "mestiza". Es Piossek quien menciona la intención de Bohórquez y su compañera rece-mapuce por aplicar en el valle Calchaquí el paradigma racial mapuce, específicamente respecto del modo de hacer la guerra: tomando cautivos españoles, según declararía el cacique Luis Aballay, "a la usanza de Chile" en la declaración del cacique Luis Aballay de 10 de mayo de 1658, citada por Piossek.

38 Según Corominas, "champurrar" es el uso vulgar en América para la voz "chapurrar", de origen incierto, quizá onomatopéyico. El Diccionario de la lengua española (RAE) define "chapurrar" como hablar mal una lengua, y en otra acepción, mezclar dos licores distintos (2014). La RAE recogió por primera vez este término (con las mismas acepciones) en 1832, si bien aclara que chapurrar es hablar mal un idioma "mezclando palabras de otros, o mezclar en el discurso especies inconexas". De donde resulta claro que originalmente la mezcla era central en la definición de las voces chapurrar y champurrar, que en algunos usos latinoamericanos se ha perdido, dando paso a lo mal hecho o al beneficio fácil. Donde síse conserva la referencia a la mezcla es en el uso mapuce, que probablemente derive de un uso chileno del siglo XIX (en Román "Champurria, com. Araucano con sangre española, mestizo. Figuradamente, araucano espańolizado"), y en cierta bebida popular de México: el atole champurrado (una bebida de maíz mezclada con chocolate).

39 Aunque nos falta todavía investigar este asunto, someramente hemos podido ver que Pascual Cońa habla de taiñ [nuestro/a] mojfvñ [sangre], para referirse a su gente, y de $k a$ [otra] mojfvñ para referirse a gente distinta; Moesbach publicó mojfuñ en ambos casos traducido como "raza". 
Luego de estos breves alcances relativos a cuestiones aún pendientes de analizar, debatir, complejizar e incluir en la discusión sobre las anterioridades y persistencias de las ideas raciales en Chile (extensibles a Argentina y otros espacios latinoamericanos), estamos convencidos de que ahondar en el estudio de lo que ha sido este último paradigma racial no solo contribuirá a los trabajos sobre raza y sobre racismos, sino que, además, permitirá conocer aquellas otras maneras de pensar e incorporar las diferencias que, sabemos, en concreto existen. Por lo mismo, nos parece que este conocimiento y reflexión bien podrían servir a la imaginación de una sociedad más justa e igualitaria.

\section{Agradecimientos}

Este artículo tiene su génesis en dos tesis doctorales financiadas por CONICYT: Tomás Catepillán Tessi, "La 'Provincia de Chile': construcción del Estado-nación en la provincia de Chiloé, 1830-1880" (2017), y Montserrat Arre Marfull, "La Raza en la literatura: Alborada de Iris y la Retórica de la Modernidad en una escritora de Vanguardia" (2018); además, hace parte de una reflexión que se inserta en el actual proyecto de la investigadora, el FONDECYT Postdoctorado 3190070: "Las ideas sobre la raza y las doctrinas racialistas en la prensa chilena durante la expansión nacional. Copiapó, La Serena, Valparaíso y Santiago entre 1840 y 1940” (2019-2021).

\section{Referencias citadas}

Aravena, G. (2017). Chiloé 1826. El proceso de incorporación de Chiloé a la República de Chile, 1813-1831. Castro: Ediciones 1826.

Araya Espinoza, A. (2010). Registrar a la plebe o el color de las castas: 'calidad', 'clase' y 'casta' en la Matrícula de Alday (Chile, siglo XVIII). En Araya Espinoza, A. y Valenzuela Márquez, J. (Eds.). América Colonial. Denominaciones, clasificaciones e identidades (pp. 331-361). Santiago: RIL Editores.

Arias, J. y Restrepo, E. (2010). Historizando raza: propuestas conceptuales y metodológicas. Critica y emancipación, II(3), 45-64. Recuperado de http://www.ram-wan.net/restrepo/documentos/historizando\%20 raza.pdf

Arre Marfull, M. (2018). La Raza en la Literatura: Alborada de Iris y la Retórica de la Modernidad en una escritora de Vanguardia, Chile, 1930-1946. Tesis para optar al grado de Doctora en Ciencias Humanas y en Estudios Comparados. Universidad Austral de Chile/Universidad de Lisboa, Chile/Portugal.

Bello, A. (2011). Nampülkafe: el viaje de los mapuches de la Araucania a las pampas argentinas. Territorio, politica y cultura en los siglos XIX y XX. Temuco: Ediciones UCT.

Bernand, C. y Gruzinsky, S. (2005). Historia del Nuevo Mundo. Tomo II: Los mestizajes, 1550-1640. México: FCE.

Berríos del Solar, S. (2017). El ADN de los chilenos y sus origenes genéticos. Santiago: Editorial Universitaria.

Bethencourt, F. (2015). Racismos. Das cruzadas ao século XX. Lisboa: Temas e Debates.

Bloch, M. (2001). Apología para la historia o el oficio de historiador. México: FCE. 
Boccara, G. (1999). Etnogénesis mapuche: resistencia y restructuración entre los indígenas del centro-sur de Chile (siglos XVI-XVIII). Hispanic American Historisal Review, 79(3), 425-461. Recuperado de https:// muse.jhu.edu/article/12303

Boccara, G. (2007). Los vencedores. Historia del pueblo mapuche en la época colonial. San Pedro de Atacama: IIAM - UC del Norte.

Braidotti, R. (2004). Feminismo, diferencia sexual y subjetividad nómade. Ventureira, G. y Femenías, M. L. (Trads.). Barcelona: Gedisa.

Briones, C. (Comp.). (2005). Cartografias argentinas: politicas indigenas y formaciones provinciales de alteridad. Buenos Aires: Antropofagia.

Burns, K. (2007). Desestabilizando la raza. En De la Cadena, M. (Ed.). Formaciones de indianidad. Articulaciones raciales, mestizaje y nación en América Latina (pp. 35-54). Colombia: Ediciones Envión.

Cáceres, R. (2000). Negros, mulatos esclavos y libertos en la Costa Rica del siglo XVII. México: Instituto Panamericano de Geografía e Historia.

Cañumil T., Cañumil D. y Berretta M. (2008). Wixaleyiñ: mapucezugun-wigkazugun pici hemvlcijka. Pequeño diccionario castellano-mapuche. Buenos Aires: El Autor.

Castillo Palma, N. (2001). Cholula. Sociedad mestiza en ciudad india. México DF: Plaza y Valdés Editores.

Catepillán Tessi, T. (2017). La 'Provincia de Chile': construcción del Estado-nación en la provincia de Chiloé, 1830-1880. Tesis para optar al grado de Doctor en Historia. El Colegio de México, México.

Chiaramonte, J. (2004). Nación y Estado en Iberoamérica. El lenguaje politico en tiempos de la Independencia. Buenos Aires: Sudamericana.

Cid, G. y Torres, I. (2009). Conceptualizar la identidad: Patria y nación en el vocabulario chileno del siglo XIX. En Cid, G. y San Francisco, A. (Eds.). Nación y nacionalismo en Chile. Tomo I (pp. 23-51). Santiago: Ediciones Centro de Estudios Bicentenario.

Constitución de la República de Chile (1833). Santiago: Imprenta de La Opinión. Recuperado de https:// www.bcn.cl/Books/Constitucion_Politica_1833/index.html\#p=1

Contreras Segura, M. T. (2013). Una ausencia aparente. Africanos y afromestizos en Valparaíso tardocolonial, 1770-1820. Revista de Historia Social y de las Mentalidades, 1(2), 105-139. Recuperado de http:// www.revistas.usach.cl/ojs/index.php/historiasocial/article/view/1545/0

Corominas, J. (1984). Diccionario crítico etimológico castellano e hispánico, CE-F. Madrid: Gredos.

Dager Alva, J. (2002). El debate en torno al método historiográfico en el Chile del siglo XIX. Revista Complutense de Historia de América, 28, 97-138. Recuperado de https://revistas.ucm.es/index.php/RCHA/ article/view/RCHA0202110097A

Darwin, C. (1860). Journal of researches into the natural history and geology of the countries visited during the voyage of H.M.S. Beagle round the world, under the command of Capt. Fitz Roy R.N. Londres: John Murray.

De la Cadena, M. (2007a). Introducción. En De la Cadena, M. (Ed.). Formaciones de indianidad. Articulaciones raciales, mestizaje y nación en América Latina (pp. 7-35). Colombia: Envión. Recuperado de http:// centroderecursos.cultura.pe/sites/default/files/rb/pdf/Formaciones\%20de\%20Indianidad.pdf 
"E aqí, pues, dos razas distintas". Paradigmas raciales en Chile (siglos XVIII-XXI): significados y deslindes...

De la Cadena, M. (2007b). ¿¿Son los mestizos híbridos? Las políticas conceptuales de las identidades andinas. En De la Cadena, M. (Ed.). Formaciones de indianidad. Articulaciones raciales, mestizaje y nación en América Latina (pp. 83-116). Colombia: Envión. Recuperado de http://centroderecursos.cultura.pe/sites/ default/files/rb/pdf/Formaciones\%20de\%20Indianidad.pdf

De la Cadena, M. (2008). Anterioridades y externalidades: más allá de la raza en América Latina. e-misférica, 5(2), 1-24. Recuperado de https://hemi.nyu.edu/hemi/es/e-misferica-52/delacadena

De Matos, P. F. (2006). As cores do Império. Representaçôes raciais no Império Colonial Português. Lisboa: Imprensa de Ciências Sociais.

Del Río Ortiz, F. (2010). Afrochilenos: Discursos oficiales en torno a los afromestizos en Chile. Actas de las IV Jornadas Experiencias de la Diversidad. III Encuentro de Discusión de Avances de Investigación Sobre Diversidad Cultural (pp. 1-21). Rosario: Facultad de Humanidades y Artes, Universidad Nacional de Rosario.

Domeyko, I. (2009[1845]). La Araucania y sus habitantes. Santiago: PUC - CIDBA - DIBAM - CChC.

El Mostrador. Todos somos mestizos: investigación echa por tierra cualquier teoría de pureza racial en Chile. Santiago. (13.09.2016). Recuperado de https://m.elmostrador.cl/noticias/pais/2016/09/13/todos-somosmestizos-investigacion-echa-por-tierra-cualquier-teoria-de-pureza-racial-en-chile/

Foerster, R. (2004). ¿Pactos de sumisión o actos de rebelión. Una aproximación histórica y antropológica a los mapuches de la costa de Arauco. Tesis para optar al grado de Doctor, Universidad de Leiden, Holanda.

Funes, P. (2018). Entre microscopios y crisoles. Raza y nación en el Sur. En Pérez Vejo, T. y Yankelevich, P. (Eds.). Raza y política en Hispanoamérica (pp. 102-146). México: Bonilla Artiga Editores - Iberoamericana - El Colegio de México.

Gay, C. (2018). Usos y costumbres de los araucanos. Santiago: Penguin Random House.

Gleizer, D. y López, P. (2015). Nación y alteridad. Mestizos, indigenas y extranjeros en el proceso de formación nacional. México: UAM - Cuajimalpa.

Goldberg, D. T. (2002). Modernity, race and morality. En Essed, P. y Goldberg, D. T. (Eds.). Race Critical Theories. Text and Context (pp. 283-306), Massachusetts, MA: Blackwell.

González Undurraga, C. (2011). De la casta a la raza. El concepto de raza: un singular colectivo de la modernidad. México, 1750-1850. Historia Mexicana, 60(2), 1491-1525. Recuperado de https://historiamexicana.colmex.mx/index.php/RHM/article/view/323

Grubessich, A. (1992). Esclavitud en Chile durante el siglo XVIII: el matrimonio como una forma de integración social. Revista de Historia, 2, 115-128. (Concepción).

Guerra, F. X. (1999). El soberano y su reino. Reflexiones sobre la génesis del ciudadano en América Latina. En Sábato, H. (Comp.). Ciudadanía politica y formación de las naciones. Perspectivas históricas de América Latina (pp. 33-61), México: FCE - Colmex.

Guevara, T. y Mańkelef, M. (2002). Kiñe mufü trokinche ñi piel. Historias de familias. Siglo XIX. Temuco: CEDM Liwen - Colibris. 
Hering Torres, M. (2007). 'Raza': variables históricas. Revista de Estudios Sociales, 26, 6-27. Recuperado de http://www.scielo.org.co/pdf/res/n26/n26a02.pdf

Hering Torres, M., Schaub, J. F. y Sebastiani, S. (2016). Editorial. Dossier. Raza: perspectivas transatlánticas. Anuario colombiano de historia social y de la cultura, 43(2), 23-30. Recuperado de http://www.scielo. org.co/scielo.php?script=sci_arttext\&pid=S0120-24562016000200001

Jara, Á. (1971). Guerra y sociedad en Chile. Santiago: Editorial Universitaria.

Kant, I. (1764). Observaciones sobre el sentimiento de lo bello y lo sublime. Edición online Librodot.com. Recuperado de https://www.ugr.es/_encinas/Docencia/Kant_sublime.pdf

Lepe-Carrión, P. (2012). El Contrato Colonial de Chile. Critica a la racionalidad impura, en la configuración racial del discurso científico, político y prácticas culturales en los siglos XVII, XVIII y XIX. Tesis para optar al grado de Doctor en Filosofía, Pontificia Universidad Católica de Valparaíso, Chile.

López Beltrán, C., Wade, P., Restrepo, E. y Santos, R. V. (Eds.). (2017 [2014]). Genómica mestiza. Raza, nación y ciencia en Latinoamérica. México: FCE.

López, P. (2017). Indígenas de la nación. Etnografías históricas de la alteridad en México (Milpa Alta, siglos XVII-XXI). México: FCE.

López, V. F. (1845). Manual de Istoria de Chile. Libro adoptado por la Universidad para la enseñanza de las escuelas de la República. Valparaíso: Imprenta del Mercurio.

Lorandi, A. M. (1997). De quimeras, rebeliones y utopias. La gesta del inca Pedro Bohórques. Lima: PUCP.

Manquilef, M. (1911). Comentarios del pueblo araucano (la faz social). Santiago: Imprenta Cervantes.

Mansilla Vidal, L. (1911). Relación genealógica de varias familias de Chiloé. Angol: El Colono.

McEvoy, C. (2011). Guerreros civilizadores. Politica, sociedady cultura en Chile durante la Guerra del Pacífico. Santiago: Ediciones UDP.

Menard, A. (2010). Canibalismo, nobilismo y heterogeneidad: comentario al libro Los Vencedores, de Guillaume Boccara. Revista de Antropología, 21, 149-178.

Mignolo, W. (2007). América: la expansión cristiana y la creación moderna/colonial del racismo. En La idea de América Latina. La herida colonial y la opción Decolonial (pp. 27-74). Barcelona: Gedisa.

Moesbach, E. W. (1936). Vida y costumbre de los indigenas araucanos en la segunda mitad del siglo XIX. Presentadas en la autobiografía del indigena Pascual Coña. Santiago: Imprenta Universitaria.

Núñez, D. (2018). Chonos, Payos y Williche del sur de Chiloé: pasado y presente de la negación de un pueblo. En VV.AA. Archipiélago de Chiloé: nuevas lecturas de un territorio en movimiento. Chiloé: CESCH.

Pérez Vejo, T. y Yankelevich, P. (2018). Presentación. En Pérez Vejo, T. y Yankelevich, P (Eds.). Raza y politica en Hispanoamérica (pp. 9-15). México: Bonilla Artiga Editores - Iberoamericana - El Colegio de México.

Pérez Vejo, T. (2003). La construcción de las naciones como problema historiográfico: el caso del mundo hispano. Historia Mexicana, LIII(210), 275-312. Recuperado de https:/www.redalyc.org/ pdf/600/60053202.pdf 
"E aqí, pues, dos razas distintas". Paradigmas raciales en Chile (siglos XVIII-XXI): significados y deslindes...

Piossek, T. (1976). La rebelión de Pedro Bohórquez. El inca del Tucumán. Argentina: s.p.i.

Quijano, A. (2014). ¡Qué tal raza! En Palermo, Z. y Quintero, P. (Comps.). Aníbal Quijano. Textos de Fundación (pp. 101-109). Buenos Aires: Ediciones del Signo.

RAE (1832). Diccionario de la lengua castellana por la Real Academia Española (7ª edición). Madrid: Imprenta Real. Recuperado de http://ntlle.rae.es/ntlle/SrvltGUILoginNtlle

RAE (2014). Diccionario de la lengua española. 23a edición. Madrid: RAE. Recuperado de https://dle.rae.es/

Rodríguez, L. (2008). Repensando las clasificaciones socio-étnicas del siglo XVIII. Indios, mestizos y espańoles al sur del valle Calchaquí (Argentina). Fronteras de la historia, 13(2), 305-326. Recuperado de https://www.redalyc.org/articulo.oa?id=83313204

Román, M. A. (1908). Diccionario de chilenismos Tomo II. Santiago: Imprenta San José.

Sánchez, M. (2015). Chile y Argentina en el escenario eugénico de la primera mitad del siglo XX Tesis para optar al grado de Doctor en Estudios Latinoamericanos. Universidad de Chile.

Sandoval Candia, O. y Arre Marfull, M. (2018). Mirada imperial sobre territorios del confín durante el fin de siècle. El caso de dos viajeras en Chile: Florence Dixie e Iris (Inés Echeverría Bello). Revista Alpha, 47, 9-30. Recuperado de https://scielo.conicyt.cl/scielo.php?script=sci_abstract\&pid=S0718$22012018000200009 \& \operatorname{lng}=\mathrm{es} \& \mathrm{nrm}=\mathrm{iso}$

Santana Pérez, J. M. (2017). Los otros: indios y negros de la colonia a la independencia. En Durante, L. M. (Ed.). Un secolo di Cuba. Storia e attualità di un'isola difficile da afferrare (pp. 19-40). Nápoles: Bordeaux.

Soutullo, D. (1997). La Eugenesia. Desde Galton hasta hoy. Madrid: Editorial Talasa.

Stavenhagen, R. (2018). El indigenismo mexicano: gestación y ocaso de un proyecto nacional. En Pérez Vejo, T. y Yankelevich, P. (Eds.). Raza y politica en Hispanoamérica (pp. 219-245). México: Bonilla Artiga Editores, Iberoamericana y El Colegio de México.

The New York Times. Elizabeth Warren Apologizes to Cherokee Nation for DNA Test. New York. (1.02.2019) Recuperado de https://www.nytimes.com/2019/02/01/us/politics/elizabeth-warren-cherokee-dna.html

Todorov, T. (2000). Nosotros y los otros. Reflexión sobre la diversidad humana. México: Siglo XXI Editores.

Undurraga Schüler, V. (2012). Usos del honor de los orígenes por las castas. En Los rostros del honor. Normas culturales y estrategias de promoción social en Chile colonial, siglo XVIII (pp. 147-167). Santiago: Universitaria - CIDBA.

UNESCO (1978). Declaración sobre la Raza y los Prejuicios Raciales. Recuperado de http://portal.unesco. org/es/ev.php-URL_ID=13161\&URL_DO=DO_TOPIC\&URL_SECTION=201.html

UNESCO (1994-2017). La Ruta del Esclavo: Resistencia, libertad, patrimonio. Recuperado de http://www. unesco.org/new/es/social-and-human-sciences/themes/slave-route/

Valenzuela Márquez, J. (2018). El matrimonio como espacio de 'desfragmentación' entre mapuche-huilliches desnaturalizados a Santiago de Chile durante la segunda mitad del siglo XVII (1669-1678). Estudios Atacameños. Arqueología y Antropología Surandinas, 58, 7-28. Recuperado de https://scielo.conicyt.cl/scielo.php?script=sci_abstract\&pid=S0718-10432018000200007\&lng=pt\&nrm=iso 
Vázquez de Acuña, I. (1992). Evolución de la población de Chiloé (Siglos XVI al XX). BAChH, 102, 403457.

West, C. (2002). A genealogy of modern racism. En Essed, P. y Goldberg, D. T. (Eds.). Race Critical Theories. Text and Context (pp. 90-112). Massachusetts, MA: Blackwell. 